\title{
Post-depositional tectonic modification of VMS deposits in Iberia and its economic significance
}

\author{
Ricardo Castroviejo • Cecilio Quesada - Miguel Soler
}

\begin{abstract}
The original stratigraphic relationships and structure of VMS deposits are commonly obscured by deformation. This can also affect their economic significance, as shown by several Iberian Pyrite Belt (IPB, SW Iberia) examples. The contrasting rheologic properties of the different lithologies present in an orebody (massive sulphide, feeder stockwork, alteration envelope, volcanic and sedimentary rocks) play a major role in determining its overall behaviour. Variscan thin-skinned tectonics led to stacking of the massive pyrite and stockwork bodies in duplex structures, resulting in local thickening and increased tonnage of minable mineralization. Furthermore, differential mechanical behaviour of the different sulphide minerals localised the detachments along relatively ductile sulphide-rich bands. The result was a geochemical and mineralogical reorganisation of most deposits, which now consist of barren, massive pyrite horses, bounded by base metal-rich ductile shear zones. Metal redistribution was enhanced by mobilisation of the base metal sulphides from the initially impoverished massive pyrite, through pressuresolution processes, to tensional fissures within the already
\end{abstract}

ductile shear zones. In NW Iberia, VMS deposits were also strongly overprinted by the Variscan deformation during emplacement of the Cabo Ortegal and Órdenes allochthonous nappe complexes, but no stacking of the orebodies was produced. Original contacts were transposed, and the orebodies, their feeder zones and the country rock acquired pronounced laminar geometry. In lower-grade rocks (greenschist facies, Cabo Ortegal Complex), solution transfer mechanisms are common in pyrite, which remains in the brittle domain, while chalcopyrite shows ductile behaviour. In higher-grade rocks (amphibolite facies, Órdenes Complex), metamorphic recrystallisation overprints earlier deformation textures. The contrasting behaviour of the IPB and NW Iberian deposits is explained by key factors that affect their final geometry, composition and economics, such as pre-deformation structure, size and mineralogical composition of the orebody and associated lithologies, temperature, crustal level, deviatoric stress and availability of a fluid phase during deformation and the style and rate of deformation.

\section{Introduction}

The ore deposits of the Iberian Pyrite Belt (IPB), southwestern Spain and southern Portugal, show perhaps the oldest written record of historical mining of volcanogenic massive sulphide (VMS) deposits in the world. Nevertheless, their genesis was only slowly understood in spite of excellent geological work, and it was not until the late 1960 s that present-day models were generally applied (e.g. Williams 1962; Febrel 1966; Rambaud 1969; Strauss 1970; 
Schermerhorn 1970, with a few precursors as Doetsch 1957 and authors cited by him). The main reason for this delay was the complex tectonic history of the IPB, which obscured the original geometry and many of the primary features and spatial relationships of the ore deposits, as compared to the relatively undisturbed geometry of the Kuroko deposits, for which the exhalative volcanic-sedimentary model had been first proposed (Ohashi 1920).

The first aim of this work is to discuss the evidence that massive sulphide orebodies are not just passive markers of post-ore deformation but that, under certain conditions, they can influence the style of deformation and the resulting morphology. This, in turn, may lead to spatial localisation and increase orebody thickness by tectonic stacking. Some examples are examined from different environments, comparing VMS from the IPB with those from less known districts in north-western Spain.

The orebodies dealt with here occur within the Iberian Massif (Fig. 1), which represents the westernmost and largest fragment of the European Variscan Belt. The Variscan orogen was developed as a consequence of the closure of the Rheic Ocean, which culminated with the Late Palaeozoic amalgamation of the supercontinent Pangea, by the collision between Gondwana and Laurussia (Matte 1986, 1991, 2001; Ribeiro et al. 1990a, b; Quesada 1991). The suture zone, as defined by ophiolites, is exposed within the Iberian Massif in both northern and southern areas and allows the distinction of Palaeozoic Gondwanan units (Cantabrian, West Asturian-Leonese, Central Iberian and Ossa-Morena zones, Fig. 1) from exotic terranes such as

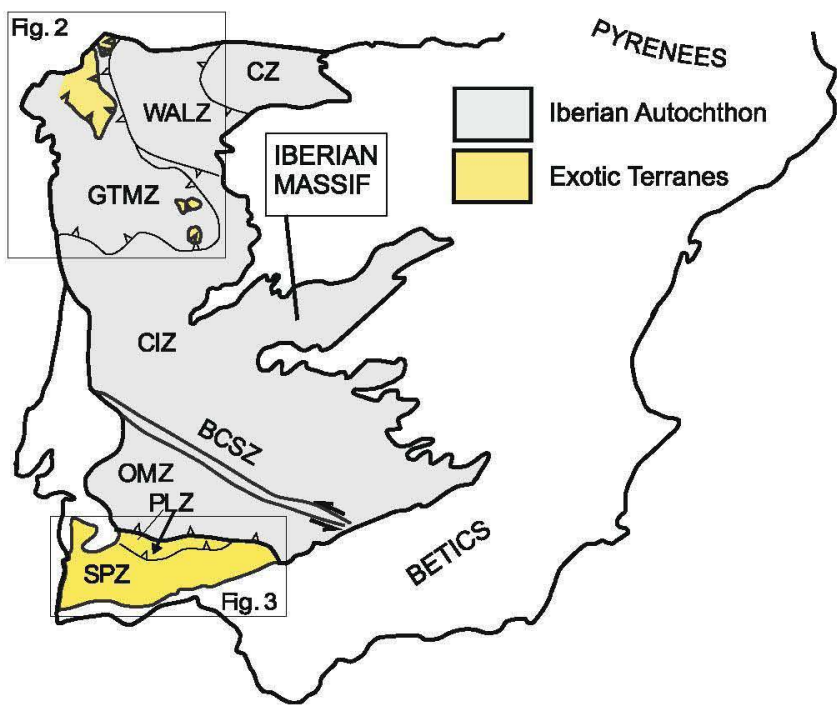

Fig. 1 Tectonostratigraphic division of the Iberian Massif $(C Z$ Cantabrian Zone, WALZ West Asturian-Leonese Zone, GTMZ Galicia-Tras os Montes Zone, CIZ Central Iberian Zone, BCSZ Badajoz-Córdoba Shear Zone, OMZ Ossa-Morena Zone, PLZ Pulo do Lobo Zone, SPZ South Portuguese Zone). Adapted from Quesada (1991) the Allochthonous Complexes in Galicia-Trás os Montes, in the north (Fig. 2), and the Pulo do Lobo and South Portuguese zones in the south (Figs. 1, 3 and 4). The VMS orebodies occur in non-Gondwanan exotic terranes, within or close to the suture zones, and their deformation was largely related to the collisional processes.

\section{VMS deposits in the IPB}

The VMS deposits of the IPB (Figs. 1 and 3) occur in the Laurussian-affinity South Portuguese Zone (Quesada et al. 1994; Leistel et al. 1998b), and their genesis is connected to trans-tensional collapse and associated igneous activity on the outer margin of this terrane during the initial stages of Variscan collision (Quesada 1998). The present structure of this region is a south-verging, thin-skinned fold and thrust belt developed above a mid-crustal basal detachment (Silva 1989; Silva et al. 1990; Quesada 1996, 1998), clearly imaged by deep seismic reflection techniques (Simancas et al. 2003) and involving tectonic transport of a few kilometres to tens of kilometres.

\section{Regional outline}

The South Portuguese Zone (SPZ) constitutes the southernmost palaeogeographic and palaeotectonic unit of the Iberian Variscan orogen (Figs. 1 and 3). Recent interpretations suggest that the SPZ is separated from the rest of the

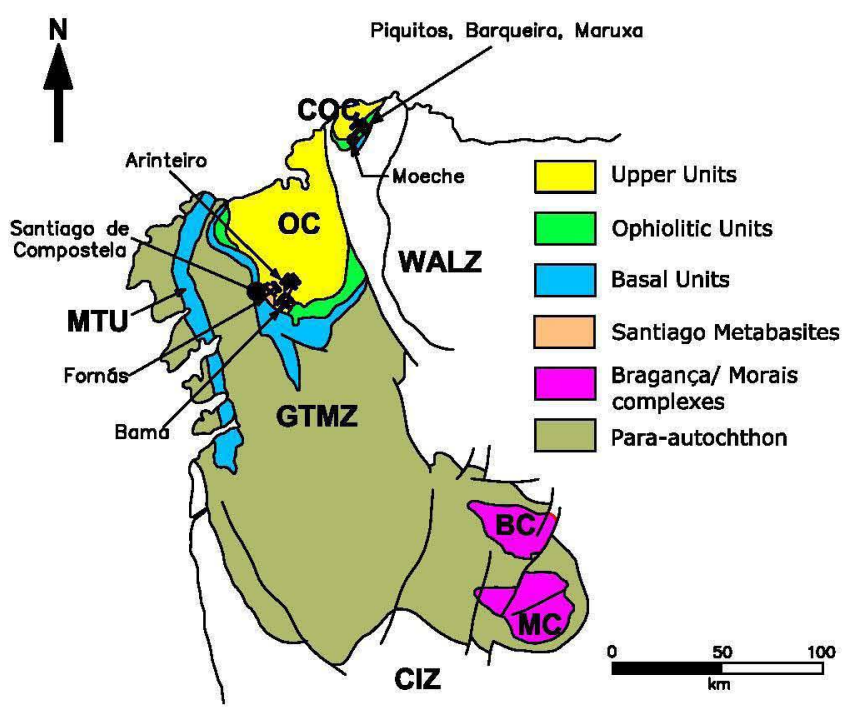

Fig. 2 Geological sketch map of NW Iberia, with location of ophiolites, allochtonous units (COC Cabo Ortegal Complex, $O C$ Órdenes Complex, MTU Malpica-Tuy Unit) and VMS deposits mentioned in text (Piquitos, Barqueira, Maruxa; Arinteiro, Fornás, Bama); GTMZ Galicia-Tras-Os-Montes Zone, WALZ West AsturianLeonese Zone, $C I Z$ Central Iberian Zone, $B C$ and $M C$ Bragança and Morais allochthonous complexes, Portugal. (Modified from Arenas et al. (2007) and Castroviejo et al. (2004a, b)) 


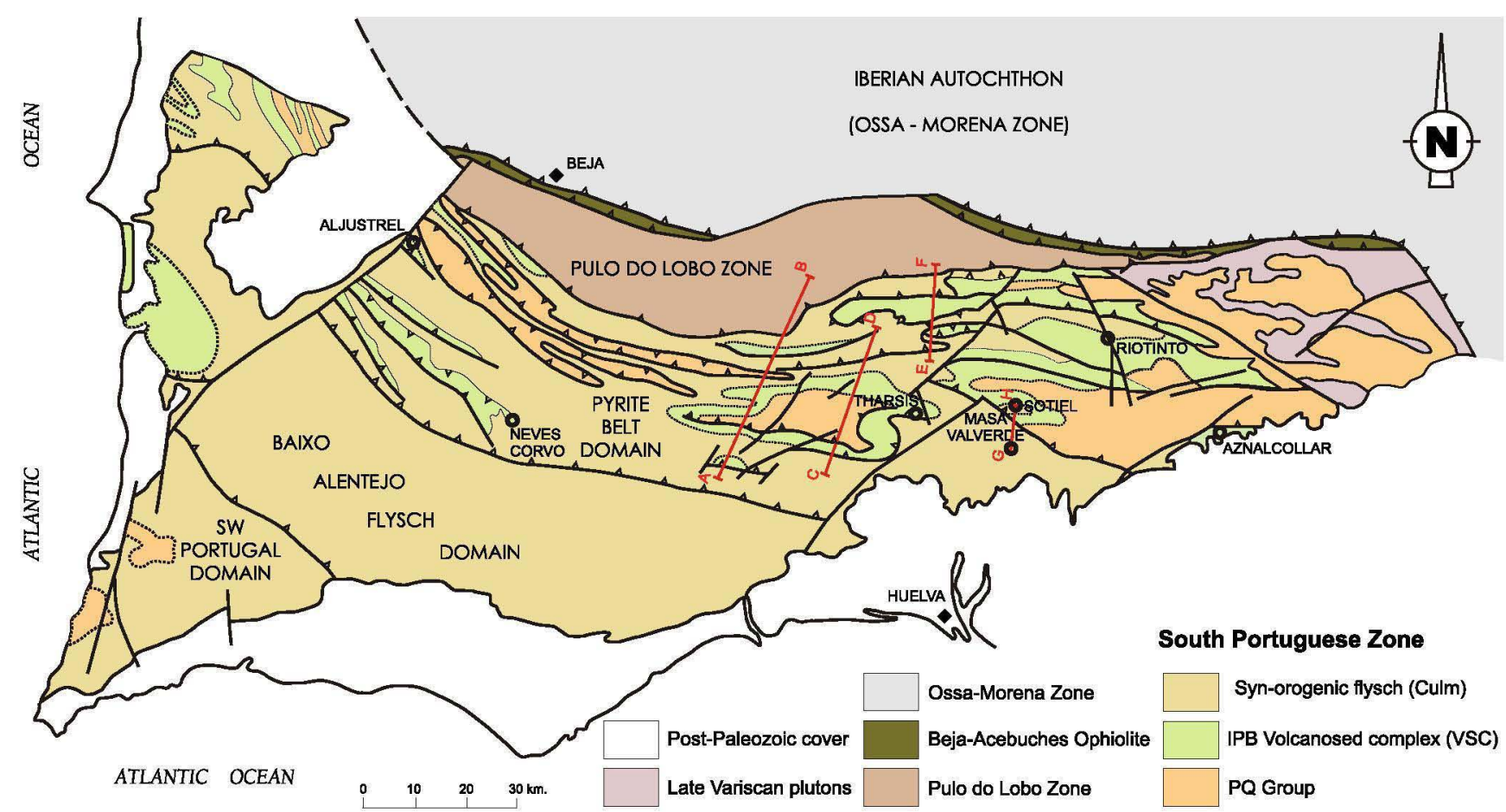

Fig. 3 Schematic tectonostratigraphic map of the southwestern Iberian Massif, showing the location of some of the largest VMS deposits in the IPB (partly adapted from Quesada 1998). Sections a-b, c-d, and e-f in Fig. 5. Section g-h in Fig. 6

orogen by a suture zone delineated by the Beja-Acebuches ophiolite and the Pulo do Lobo accretionary terrane (Munhá et al. 1986; Ribeiro et al. 1990a; Quesada 1991, 1992; Quesada et al. 1991, 1994). In this context, the SPZ is envisaged as an exotic terrane relative to the Gondwanan affinity Iberian Autochthon. Correlation of the SPZ is, however, hindered by the extremely reduced stratigraphic record presently exposed. An extension around the IberoArmorican Arc (Matte and Ribeiro 1975) into SW England and the Rheno-Hercynian Zone in Central Europe has been suggested (Oliveira et al. 1979; Quesada 1992; Oliveira and Quesada 1998). If this correlation is correct, then the SPZ would represent a southern segment of the Eastern Avalonia continental margin of southern Laurussia.

The oldest rocks exposed within the SPZ are the siliciclastic successions of the so-called Phyllite-Quartzite Group or simply PQ (Schermerhorn 1971). These rocks have similar characteristics throughout the zone and represent late Devonian platform sedimentation on a passive margin (Quesada et al. 1991). According to Quesada (1991, 1998) oblique collision between the SPZ and the southern margin of the Iberian Autochthon led to progressive changes in tectonic conditions. Initially, while oceanic lithosphere still remained lateral to the collision zone, marginal blocks of the SPZ escaped laterally and led to trans-tensional collapse and crustal thinning. Extended parts of the SPZ acquired a horst and graben structure coeval to emplacement of large volumes of bimodal volcanic rocks (see Fig. 4a). The marginal units affected by this trans-tensional regime now form the so-called Iberian Pyrite Belt division of the SPZ. This is stratigraphically characterised by a variable and diachronous Early Carboniferous Volcano-Sedimentary Complex (VSC; Schermerhorn 1971), which contains the VMS deposits.

Once the lateral escape of units was no longer possible, persistent convergence led to A-type subduction of the SPZ beneath the Iberian Autochthon margin (see Quesada 1991 and Fig. $4 b$ and c). These changing conditions caused the inversion of pre-existing extensional structures that formed at the same time as the VMS deposits. Former transfer faults became lateral ramps and accommodated most of the sinistral oblique component of convergence. The main results of this tectonic regime were: (1) the formation of a thin-skinned, southerly propagating fold and thrust belt rooted in a mid-crust basal décollement (Fig. 4d) and (2) the transformation of the pre-existing extended margin into a foreland basin onto which a southerly migrating Late Viseán to Early Westphalian flysch succession (Culm Group, Schermerhorn 1971) was deposited in front of, and sourced from, the advancing nappe pile.

The main structural elements that now form the architecture of the SPZ are the thrusts and folds (Figs. 3 and 5). The structures show fractal behaviour from the microscopic to the regional scale (Quesada 1996), which implies that the geometries at depth should be similar to those exposed at the surface, at least down to the basal 
Fig. 4 Sketch tectonic model showing the evolution of the SW Iberian Massif during Variscan convergence. a Map view showing sequential escape of units from the margin of the SPZ during initial collision stages, resulting in localised transtension; section views of, $\mathbf{b}$ plate tectonics situation prior to Variscan collision; c early collisional stage (transtension); d final situation after the main collisional event. (No scale)

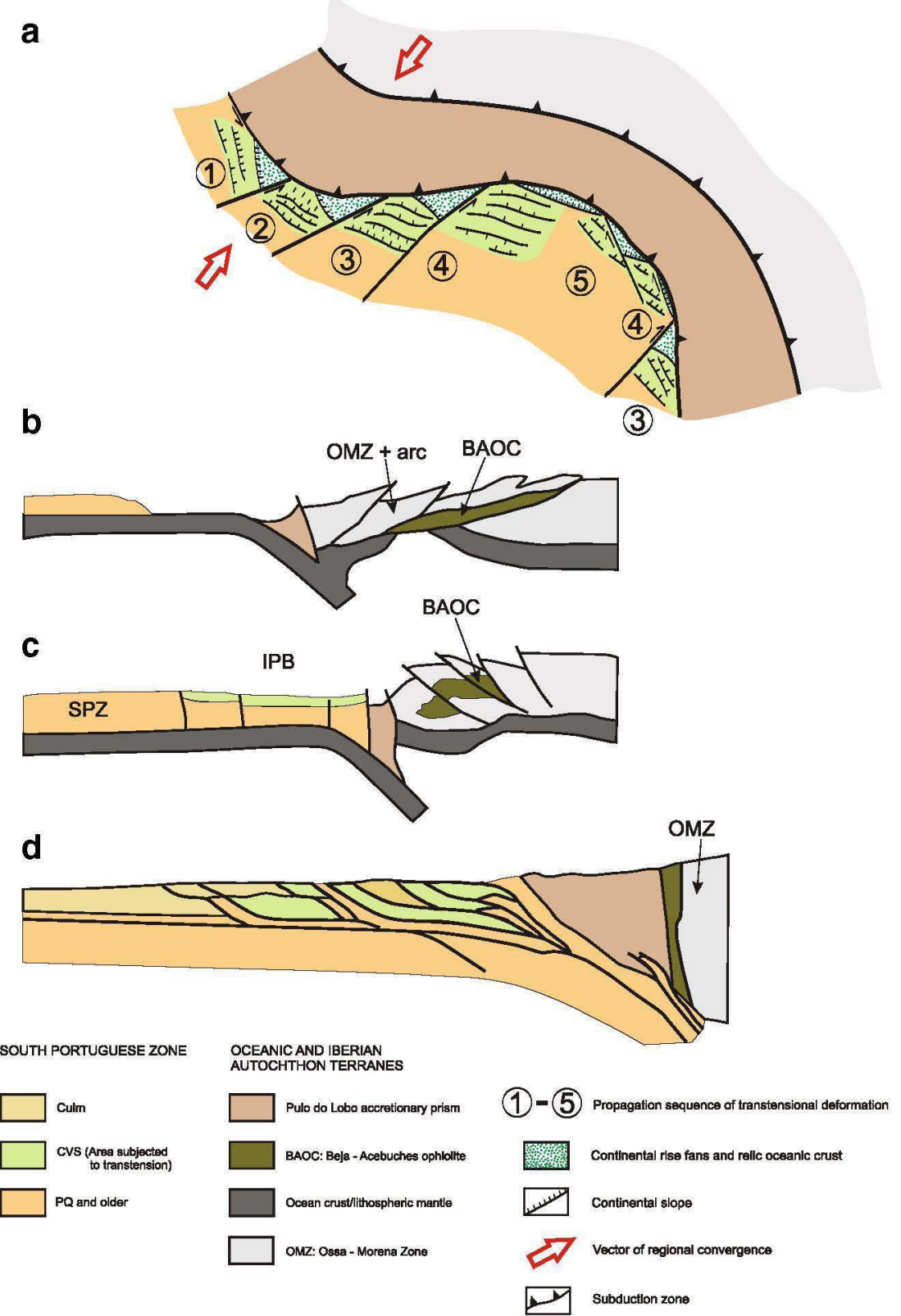

(1996) and by Ruiz et al. (2002), but the structure was only summarily dealt with. The description below focuses on the structure of the deposit, which provides one of the best examples of tectonic stacking at the deposit scale in the IPB.

The MVD occurs in the Valverde del Camino district (Figs. 3, and 6a, b). The late Devonian PQ unit and the overlying Early Carboniferous VSC unit crop out to the east, where they form a NW-SE trending anticline that is disected by SW verging thrust faults. The $\mathrm{S} 1$ (axial plane) cleavage strikes $\sim \mathrm{N} 110^{\circ} \mathrm{E}$ and dips northwards, is conspicuous in most of the lithologies and is the best reference frame for structural correlations. This is important because the VSC lithologies may be very monotonous or extremely altered and are consequently not reliable as guides. 
Fig. 5 Regional scale schematic cross-sections showing the thinskinned imbricate structure typical of the IPB (please compare with the outcrop and microscopic structures shown on Figs. 12 and 13, respectively). Solid lines faults, dashed lines cleavage, dotted line stratigraphic contacts. Same colours as Figs. 3 and 4; dark brown Pulo do Lobo Zone, orange PQ Group, green VSC in the IPB, light brown Culm flysch
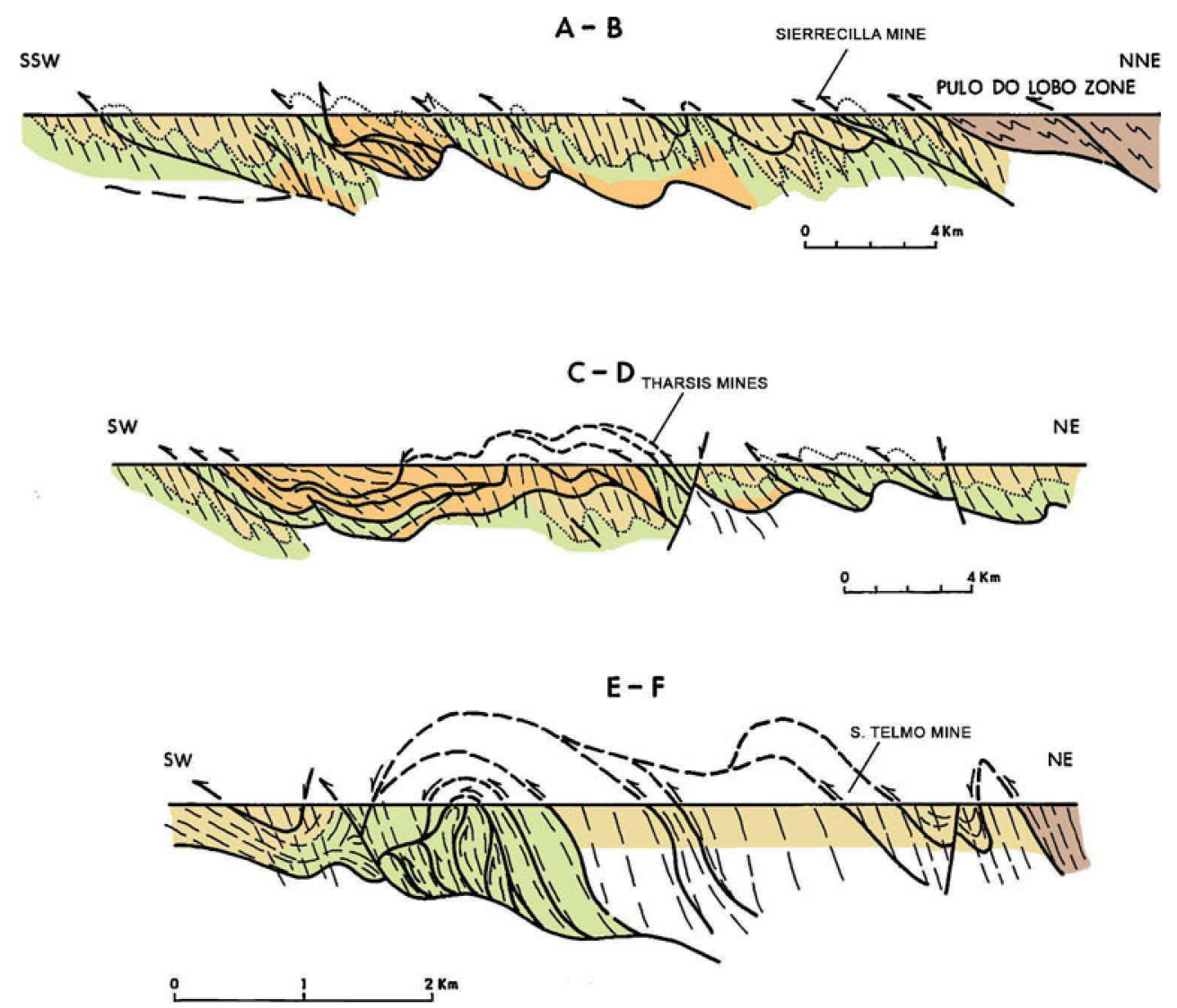

The MVD lies to the west, beneath $\sim 500 \mathrm{~m}$ of Culm cover (Fig. 6a). The NNE-SSW section (Fig. 6b) has been extended further north (Fig. 3, out of the frame of Fig. 6a: Section $\mathrm{G}, \mathrm{H}$ ) to show the general structure and also to allow a comparison of the MVD (SSW end of the profile) and Masa Migollas (NNE) deposits, the latter which is overthrust by the PQ Unit.

Field reconnaissance in the area above the MVD demonstrated the existence of a NW-SE trending, high-angle, strikeslip fault (Southwestern Fault, Fig. 7), which has a 50-m thick breccia zone and a dextral displacement of some 1 to $2 \mathrm{~km}$. This fault explains why some drill holes (A-4, A-9 and A-24) on the SW side of the deposit are barren. Another important north trending high-angle fault (Eastern Fault, Figs. 7 and 8) has been demonstrated from analysis of the drill core data but is not seen in outcrop. This fault cuts through an array of earlier NEdipping thrust planes (sections 3 and 9, Figs. 9 and 10), formerly interpreted as the upper limit of the massive sulphide body. These two high-angle faults separate three blocks with different structure. Only the central (Masa) block hosts the Masa Valverde body, which is limited on both sides (SW and E) by the high-angle faults (Figs. 7, 8, 9 and 10). The limits of the MVD to the north and northwest are undetermined.
It can be concluded that the Masa Valverde ore deposit comprises a blind antiformal body with several structurally stacked massive sulphide and stockwork lenses (Fig. 8a). The anticlinal axis plunges gently to the NW. To the north, the Masa dips below the allochthonous (thrust) units intersected by DDH A-25 (Fig. 7). The surface geology is only of limited value to establish the internal structure of the MVD, since the rocks outcropping above the deposit (Culm cover) are all post-ore and unrelated to the genesis of the deposit. A detailed and reliable correlation of all the borehole information is required, including petrographic, mineralogical, chemical and structural information.

The lithologies present in the MVD area are summarised in Table 1. A detailed description of these lithologies can be found in Castroviejo et al. (1996) and Gable et al. (1997a, b, 1998). What is relevant for our purpose is the strong dynamometamorphic overprint of most of the lithologies found in the Masa Unit. Numerous mylonites and breccias (Figs. 11a-c) are conspicuous not only at the base of the Culm cover in the ductile graphitic black slates but also in the VSC and particularly at the top of the massive sulphide bodies (ultramylonites). These define a detachment plane at the VSC-Culm contact (Fig. 11a, b). Furthermore, some rocks traditionally identified as chert or Mn-jaspilites and thought to belong to a particular horizon of siliceous and Mn-bearing 


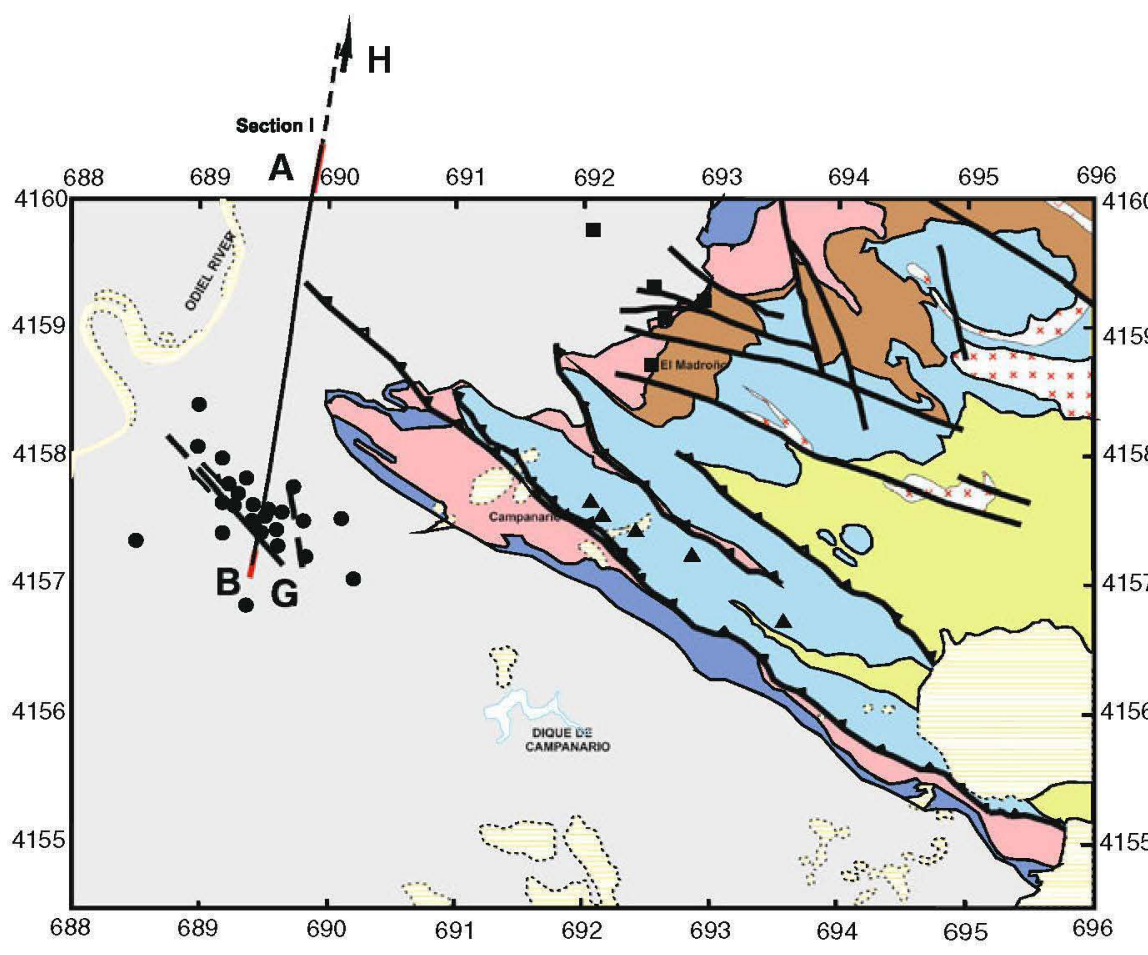

NNE H
SECTION I

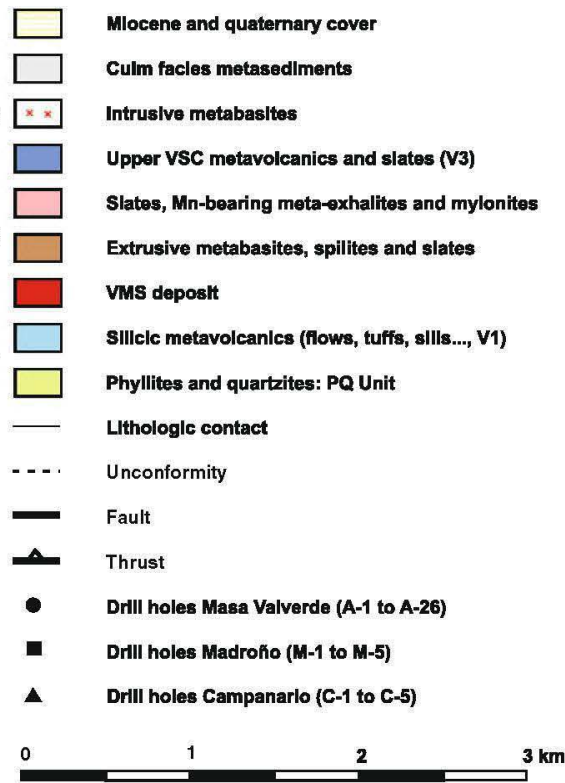

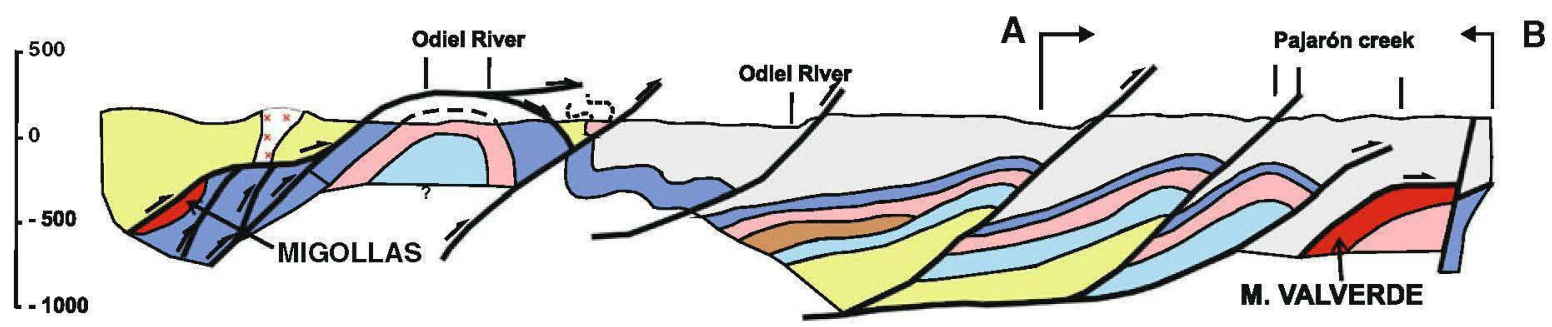

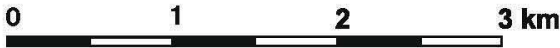

Fig. 6 Surface geology (a) and cross-section (b) of the Valverde del Camino area, above the blind MVD (Masa Valverde Deposit), with location of exploration boreholes. The cross-section, showing at its SSW end the MVD, has been extended to the north to show the

position of the blind Masa Migollas deposit, Sotiel Mine, below the PQ unit. The interval $A-B$ of the cross section that occurs on the map area is indicated; the position of the whole section $(G-H)$ is shown in Fig. 3

exhalites ("Formación Manganesífera", Ramírez Copeiro and Navarro 1982) include fine-grained silica (tcarbonate) rocks that could result from hydrothermal circulation related to dynamo-metamorphic events and have no relationship to any particular stratigraphic horizon. For example, the quartz mylonites that are related to thrust planes in the surroundings of the old Calañesa Mn mine, near the Campanario or C-drill sites (Fig. 6a). These rocks comprise one more class of silica rocks to those recognised by Leistel et al. (1998a, b).

The Masa Valverde deposit is a volcanogenic massive sulphide orebody of a type common in the IPB:

- It has a $\mathrm{Zn} /(\mathrm{Zn}+\mathrm{Pb})$ ratio of about 0.75 (Castroviejo et al. 1996) which puts it in the $\mathrm{Zn}-\mathrm{Pb}-\mathrm{Cu}$ class of VMS deposits (Lydon 1992); the large size and abundance of sedimentary rocks are consistent with the Iberian type (Sáez et al. 1999).

- Mineralogy (Castroviejo et al. 1996; Ruiz et al. 2002): (1) the massive sulphide bodies (dominantly metapyritite) have pyrite as the main ore mineral and variable amounts of sphalerite, chalcopyrite, galena and tetrahedrite, with minor to trace amounts of arsenopyrite, pyrrhotite, marcasite, stannite, bournonite and precious metals (native gold and silver/electrum) as well as Ti-oxide minerals (rutile, anatase, titanite/leucoxene); (2) these same minerals are also found in the stockwork bodies, as well as minor to trace amounts of boulangerite, wittichenite and cosalite or galenobismuthite. The main gangue minerals are quartz, 
Fig. 7 Vertical projection map (equal depth contours, referred to the sea level) of the top of the Masa Valverde Deposit, showing the position of: (1) the main A (Autonomía) diamond drill holes which intersected the MVD (see Fig. 6a), (2) the profiles represented in Figs. 9 and 10 (sections 1 to 9) and (3) the main late faults limiting the ore body to the Southwest and to the East (see text and Fig. 8a for explanation)

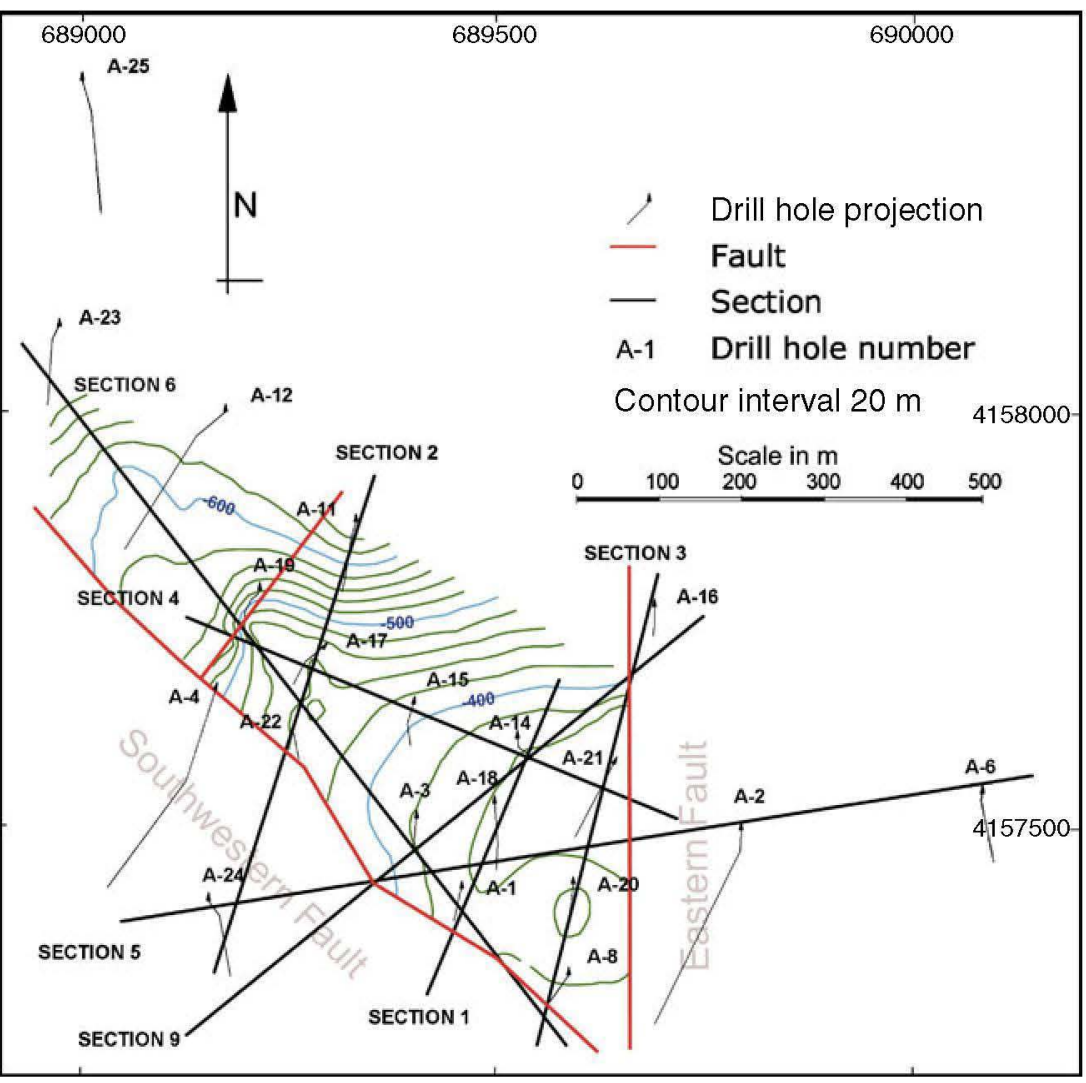

carbonate (mainly ankerite), sericite, chlorite, clay minerals, zircon and epidote. The primary VMS deposit textures (Fig. 11e) are commonly overprinted by recrystallisation and intense deformation fabrics (Figs. 11c, d, f);

- The massive sulphide bodies are interpreted as sedimentary exhalative mineralisation and the stockwork veins as the hydrothermal feeders. The close spatial association between the massive sulphides and the stockwork suggests that the ore deposit is proximal in character (like Río Tinto). Due to the widespread thrusting, it is impossible to define the original contacts between the formations.

- The geometry of the deposit may be described as an antiformal stack formed by tectonic transport of various sheets of stockwork and of massive sulphide bodies. A roof thrust plane below the Culm metasediments limits the top of the deposit. The bottom of the deposit is not defined with absolute certainty (Fig. 8a).

The interpretation of the MVD structure relies on revision of all the previous drill core logs and detailed study of selected drill cores. These logs were then correlated for structural interpretation by means of a computer-aided methodology, ${ }^{1}$ and the two sets of longitudinal and transverse sections shown in Fig. 7 were produced. Geochemical data,

\footnotetext{
${ }^{1}$ Details about the methods and software used can be obtained upon request from the third author. Interested readers are also referred to Laing (1977).
}

supported by quantitative information on ore compositions obtained by digital image analysis on polished sections, are consistent with the structural interpretation. These data also suggest the presence of thrust units by abrupt changes in metal ratios, particularly $\mathrm{Cu} / \mathrm{Cu}+\mathrm{Zn}+\mathrm{Pb}$ (Castroviejo et al. 1996). This can be explained by the structural superposition of sheets or blocks of the orebody that were originally in different positions within the deposit.

The large size of the stacked deposit made possible its detection by the geothermal anomaly that the thermally conductive sulphide body produces (chimney effect, Gable et al. 1997a). This geothermal technique was used to distinguish gravimetric anomalies produced by VMS deposits from dense rocks like gabbro (Fig. 8b). The geometric structural model established for the MVD is consistent with and helped interpret the geothermal model.

The results of geological mapping, drill core logging and the various other techniques are combined on the crosssections (Figs. 9 and 10). These sections show the allochthonous and stacked structure (at the deposit scale) of many of the lithologies and the massive sulphide bodies. The structure implies large displacements and out of sequence thrusting (as suggested by the slices of VSC host rock in the Culm Cover: Fig. 9). The stacked structure also results in an important tectonic accumulation of sulphide in the limited space of the Masa Block (tectonic thickening). However, it is important to note that the original volume of 
Fig. 8 a Block diagram showing the geometry of the blind Masa Valverde orebody (Masa Block), seen from the NE with elevation of $30^{\circ}$. The eastern boundary is an abrupt tectonic contact, marked by the plane of the Eastern Fault, on which the inner structure of the sulphide body has been drawn for reference. VSC

Volcanic-Sedimentary

Complex. (Grid $20 \mathrm{~m} \times 20 \mathrm{~m}$; interval between contour lines, $20 \mathrm{~m}$; the geographical coordinates at the base allow a comparison with Figs. $\mathbf{b}$ and 7. The square dashed shows the position of (a), but this is rotated $90^{\circ}$ clockwise, as indicated by the $\mathrm{N}$ position; the vertical scale to the left shows absolute depth in $\mathrm{m}$, referred to sea level). $\mathbf{b}$ Representation of the isotherms at $100 \mathrm{~m}$ depth, obtained from thermal measures in the $A$ boreholes located in Fig. 7 (the main faults are projected for reference; the geographical coordinates show that the area is about twice that of Fig. 7). The Masa Valverde orebody is clearly defined by the main thermal anomaly, as shown in the comparison of subpanels a and $\mathbf{b}$. The values $>21.60^{\circ} \mathrm{C}$ to the SE of (b) suggest a new anomaly that might point to another concealed, unexplored sulphide body (modified from Gable et al. 1997b)

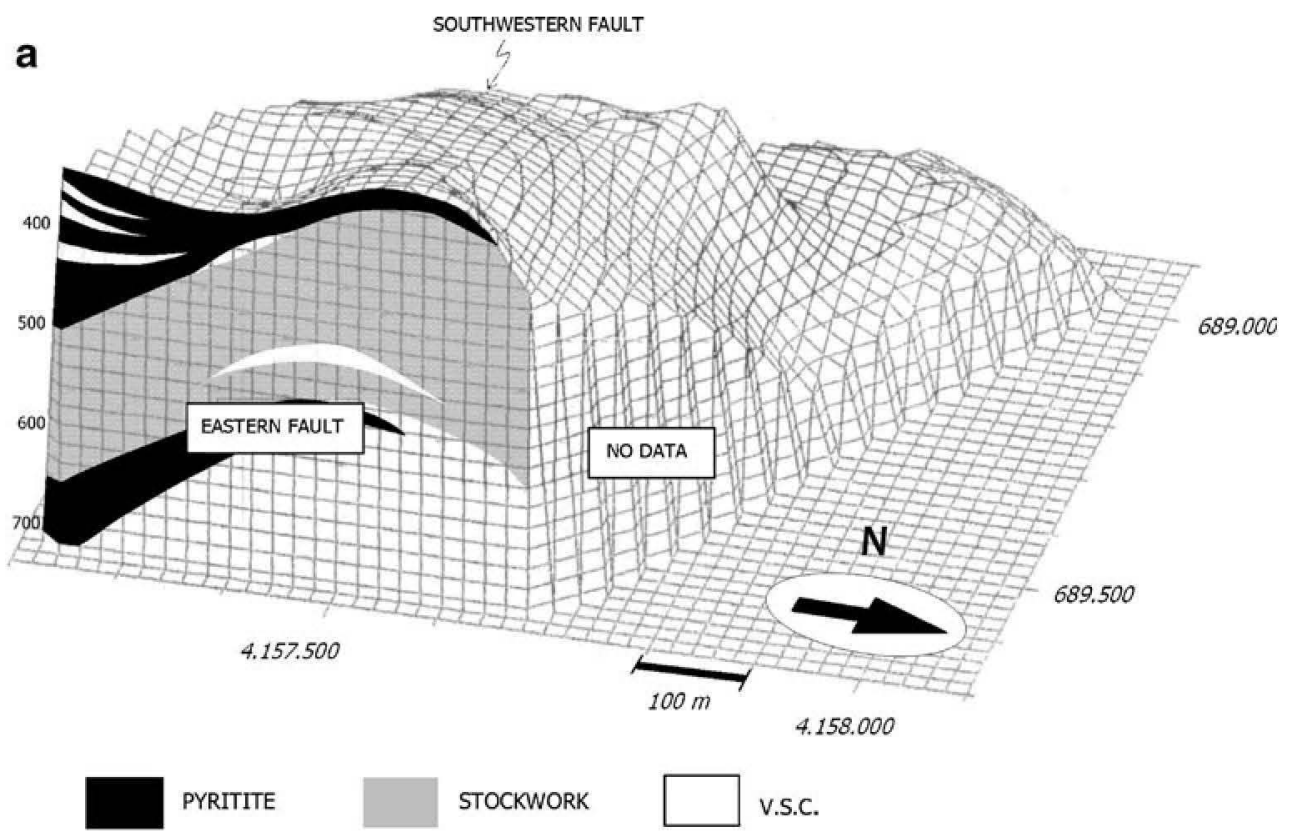

b

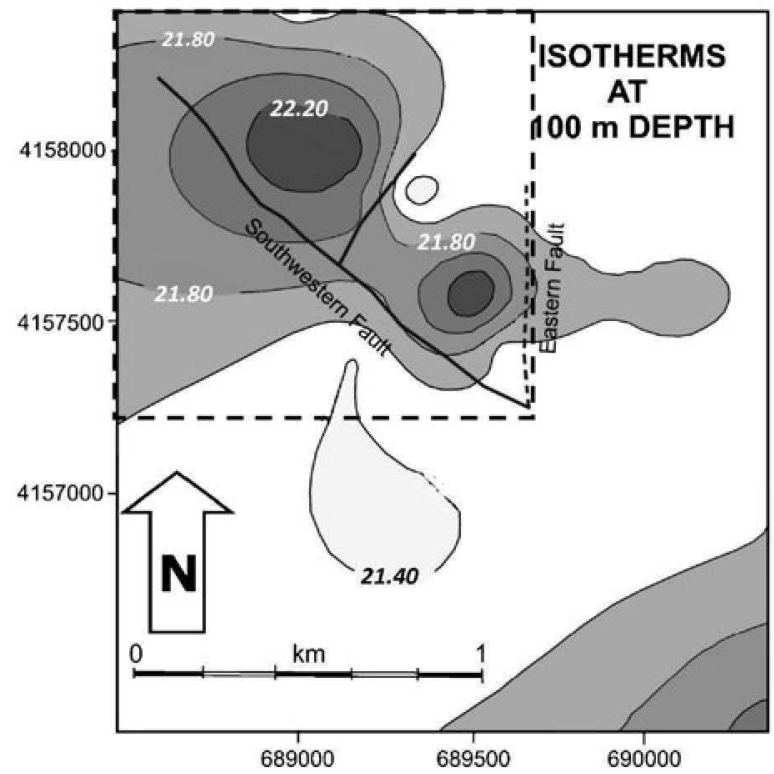

the stacked MVD can no longer be measured. It has certainly been strongly reduced by the two late Southwest and East Faults, which cut across the deposit at its core where it is still quite thick $(200-300 \mathrm{~m}$, see Fig. 9, sections 1 and 3 ). The original tonnage of the sulphide bodies before faulting was probably much more than the 80-100 Mt estimated for the known resource.

Other examples from the IPB

Similar features exist in other VMS deposits of the IPB. Many authors report remobilisation of metals as a common feature, and tectonic stacking of massive sulphide bodies has been observed at most major deposits.
Remobilisation can be related to metamorphism (Marignac et al. 2003, Tharsis) and/or to tectonics (Quesada 1998). In the Tharsis and La Zarza areas, Chauvet et al. (2004) proposed the formation of sulphide-bearing deformation veins, either superimposed on the primary feeder stockwork or emplaced within cleavage and shear planes related to the regional southverging tectonics. Mckee (2001) shows remobilisation of the more ductile ore minerals (galena, chalcopyrite, sphalerite) into shear zones during the Variscan orogeny as a common feature in the Aguas Teñidas Este deposit. Other authors report tectonic-hydrothermal base and precious metal refining, mainly for $\mathrm{Cu}$ or $\mathrm{Au}$ (NevesCorvo, Aznalcóllar, Tharsis as reviewed by Tornos 2006). 
Fig. 9 Structure of the Masa Valverde orebody, shown along transverse sections $1-3$ of Fig. 7. The repeated thrusts stack massive sulphide and stockwork lenses, enhancing the thickness of the orebody (see text for discussion)
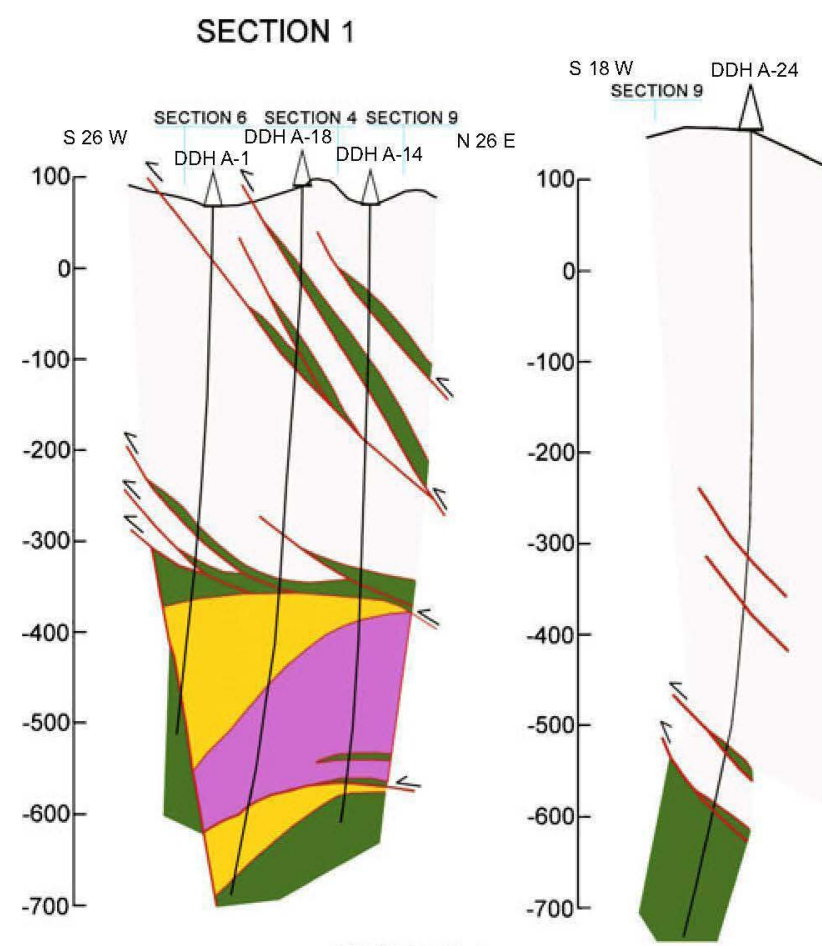

SECTION 2

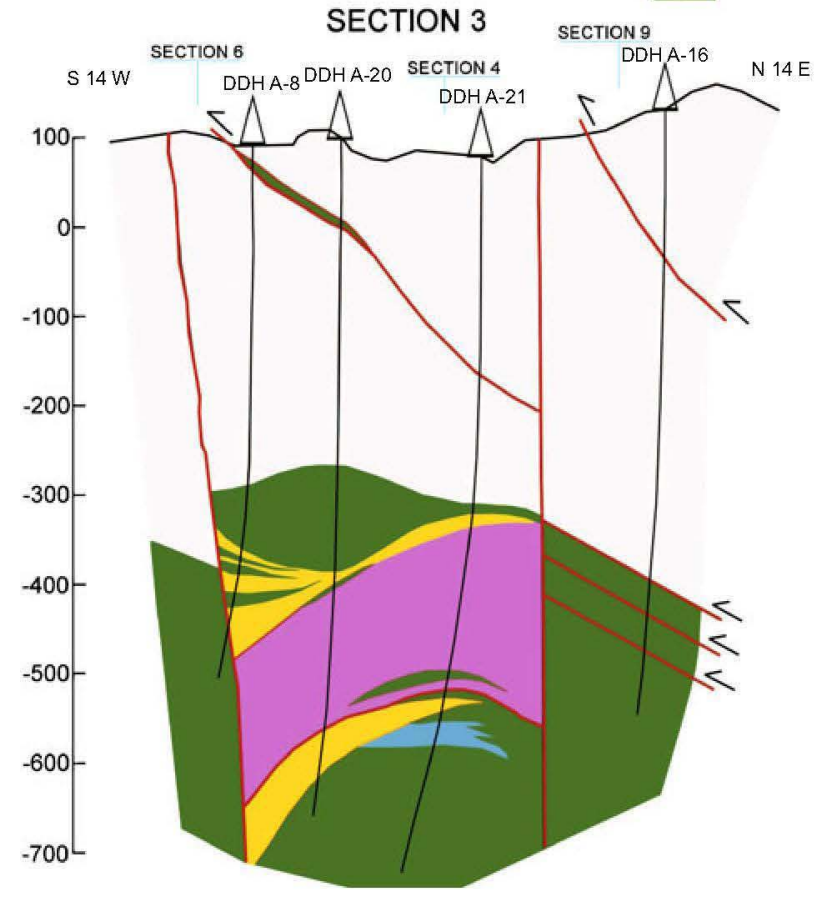

Explanation

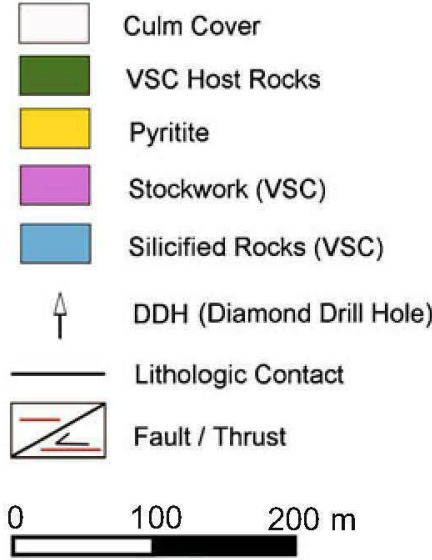

Nevertheless, from a quantitative point of view, taking into account the total tonnage involved, remobilisation seems to be subordinate, mainly causing local re-distribution of metal grade, whereas tectonic stacking dramatically affects the whole deposit.

The effects of tectonic transport at a larger scale can be illustrated by some relevant examples. At Neves Corvo, Portugal, Relvas et al. $(2002,2006)$ found evidence for syn- and post-ore modification events, such as "slide displacement of massive sulphide lenses" and "low angle thrusting". Furthermore, the detailed stratigraphy of the mine area (Oliveira et al. 2004) shows that it "is characterised by a stacked pile of thrust sheets", so that "no rooted autochthonous stratigraphic sequences exist in the mine area". The same applies for the Tharsis deposit, where the massive ore lenses are tectonically stacked within the shale and stockwork ore (Tornos et al. 2008). At Aznalcóllar, overthrusting of stockwork mineralisation onto massive sulphides caused tectonic repetition of massive and stockwork orebodies (Almodóvar et al. 
Fig. 10 Structure of the Masa Valverde orebody, shown along longitudinal and transverse sections 4,6 and 9 of Fig. 7 . The repeated thrusts stack massive sulphide and stockwork lenses, enhancing the thickness of the orebody (see text for discussion)
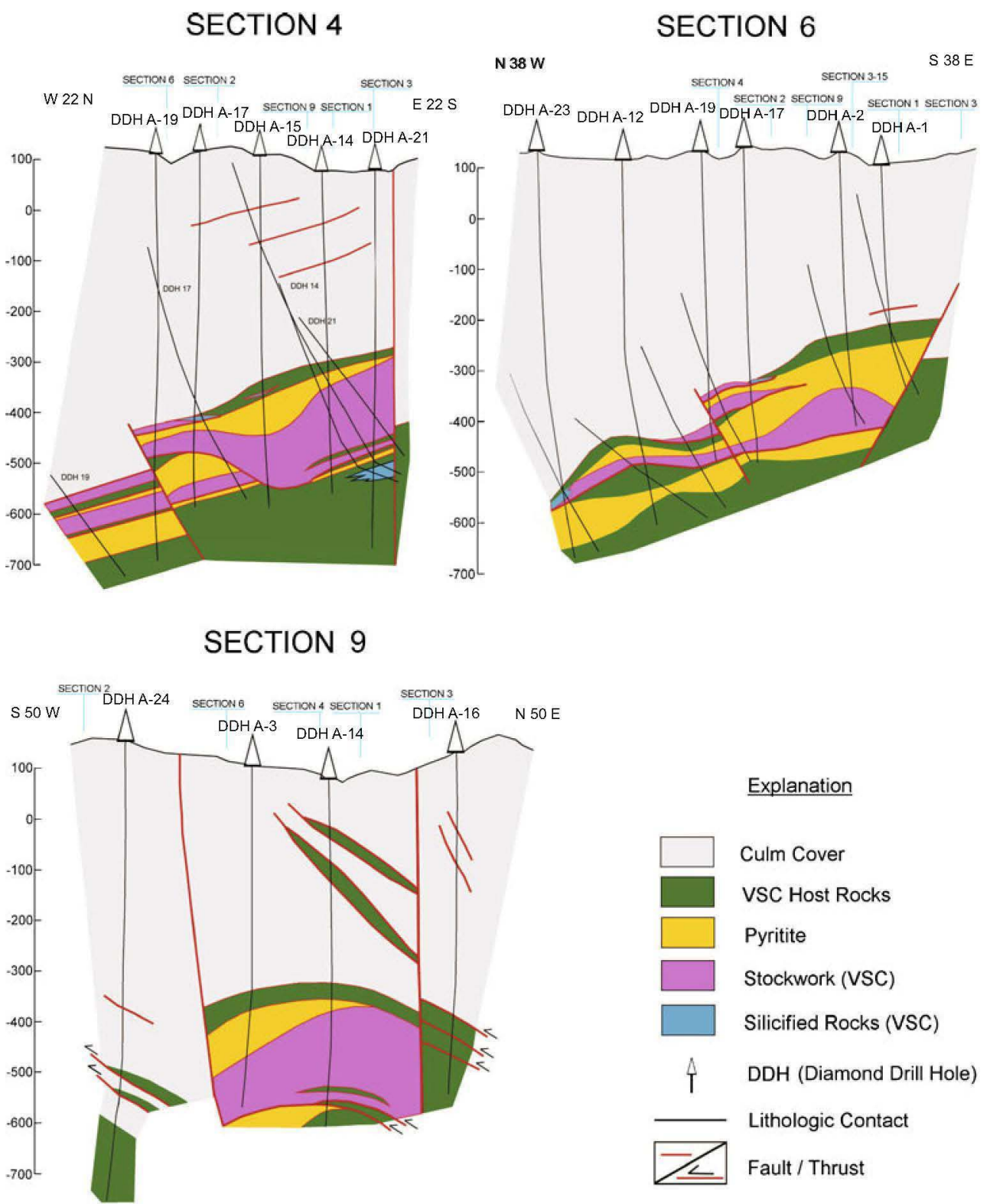

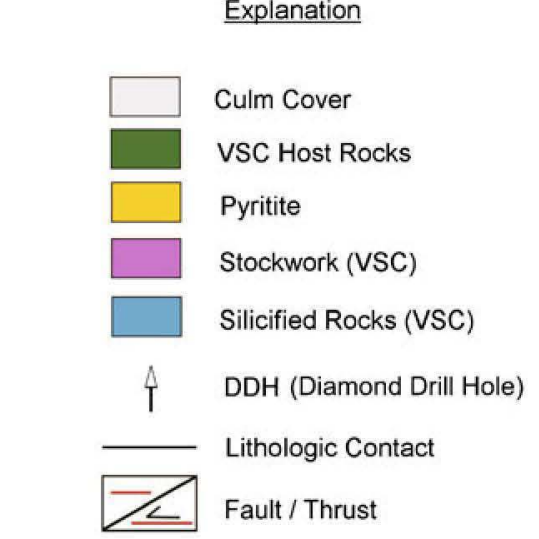

$0 \quad 100 \quad 200 \mathrm{~m}$
1998). Tornos et al. (1998) showed that the Filon Norte (Tharsis) deposit comprises up to seven stacked sheets of massive sulphides and shales hosting a stockwork zone (Fig. 12c), so that "the present configuration and thickness of the orebody is due to the tectonic stacking of a thin and extensive blanket (2-4 $\mathrm{km}^{2}$ ) of massive sulphides with low aspect ratio". Tectonic stacking is also observed in La Zarza, evidenced by thrust slices of massive sulphides and by thrusting of the stockwork over the massive sulphide bodies (Pawels et al. 2002, see also Fig. 12d). The discovery of the Masa Migollas orebody, buried below the overthrust PQ unit (Santos et al. 1993, in Leistel et al. 1998a, b; see also Fig. 6b) highlights the importance of structural concepts for exploration in the IPB.
The structure of VMS orebodies in the IPB

Within the SPZ, two elements make the IPB unique: namely the Early Carboniferous Volcano-Sedimentary Complex and the associated VMS ore deposits. Both provide evidence for early crustal extension.

The observation that the vast majority of the IPB orebodies are aligned along, or are in the vicinity of, regionally important Variscan thrusts or lateral ramps, together with the association of strong hydrothermal alteration with lateral ramps, led Quesada $(1996,1988)$ to interpret the present thin-skinned architecture to be the result of tectonic inversion of the previous horst and graben structure (Fig. 4c and d). In his reasoning, he envisaged the extremely altered 
Table 1 Lithologic characterisation of the Masa Valverde ore and host rocks

\begin{tabular}{|c|c|c|}
\hline \multirow[t]{2}{*}{ Main unit } & \multicolumn{2}{|l|}{ Lithologies observed } \\
\hline & Surface (Valverde area) & Drill Cores \\
\hline Culm & Slates Metagreywackes & $\begin{array}{l}\text { Silty slates, metagreywackes } \\
\text { Protomylonites, phyllonites, } \\
\text { Carbonate rocks } \\
\text { Black slates (strongly deformed) }\end{array}$ \\
\hline VSC & $\begin{array}{l}\text { Slates Metajaspilites/meta-exhalites Breccias, } \\
\text { mylonites and quartzmylonites Purple slates } \\
\text { Metarhyolites/-dacites, and their porphyritic } \\
\text { and pyroclastic equivalents Metabasites } \\
\text { (spilites, albite dolerites) }\end{array}$ & $\begin{array}{l}\text { Micro-nodular ultramylonites Slates and metacinerites Metajaspilites } \\
\text { and meta-exhalites Quartz-mylonites and silicified rocks } \\
\text { Carbonate rocks and marbles Breccias, mylonites with various } \\
\text { protoliths Cemented mylonite breccia Purple slates Massive } \\
\text { sulphides }\left(\mathrm{P} ; \mathrm{C} ; \mathrm{B}^{\mathrm{a}} \text { ): Metapyritite, pyrite-mylonite, pyrite-breccia, }\right. \\
\text { etc. Occasional interlayered slaty or spongy silicate lenses } \\
\text { (azufrones) Stockwork lithologies: chloritites, chlorite/quartz- } \\
\text { sericite rocks, quartz-sericite rocks; ores and veinlets: sulphide- } \\
\text { cemented breccias, veinlets and disseminations (P, C, B types }{ }^{\mathrm{a}} \text { ) } \\
\text { Felsic metavolcanics, and their porphyritic and pyroclastic } \\
\text { equivalents(quartz- or felspar-rich, these mayshow peperitic } \\
\text { contacts) Metabasites (spilites, or altered basalts and dolerites) }\end{array}$ \\
\hline PQ & Metalutites, sandy or silty metalutites & Not intersected \\
\hline
\end{tabular}

$P$ pyritic, $C$ complex, $B$ base metal-rich

${ }^{\mathrm{a}} \mathrm{C}, \mathrm{B}$ and $\mathrm{P}$ defined after amount of base metal ore as $\%$ of total sulphide $\geq 5,5-3$ and $<3$, respectively

zones to offer the best conditions for localising detachments during the subsequent transpressional inversion stage, since they contained the largest rheology contrasts (soft alteration assemblages and base metal sulphides, competent massive pyritite and unaltered country rocks, which are generally intermediate in rheology).

Many VMS deposits in the IPB, previously attributed to stratigraphic superposition of several exhalative layers, are now interpreted to be secondary tectonic stacks of thrust sheets (Leistel et al. 1998a, b; Tornos et al. 1998; Tornos 2006; Quesada 1998). This tectonic stacking provides an explanation for one of the most striking features of the IPB orebodies, i.e. their thickness that locally may reach more than $100 \mathrm{~m}$. Most of the thickest deposits in the IPB consist of several horses stacked against a footwall ramp and delineate a duplex structure (see Figs. 12 and 13 for examples at various scales). Inversion tectonics in these cases produced local accumulation of ores that were originally spread over a much wider area. Obviously, this has had an important influence on the economic value of the deposits.

Apart from the fact that some IPB orebodies might correspond to sheet-like deposits formed in brine pools (Tornos et al. 2008), another significant difference of many IPB massive ores with respect to other less deformed examples elsewhere is the lack of distinct metal zoning that typifies exhalative sulphide mounds. Many of the massive orebodies contain alternating base metal-rich and barren zones, apparently lacking any systematic geochemical arrangement. Careful field examination allows recognition of sigmoidal barren bodies (millimetre to metre scale, Figs. 12b and 13a, b), consisting of massive pyritite, surrounded by an anastomosing network of thinner bands (centimetre to decimetre thick) rich in base metal sulphides. Petrographic analysis shows that the pyritite ore lenses exhibit an isotropic granular texture with pressure-solution structures at the grain boundaries and several generations of pressure solution seams across the lenses (Fig. 13a and b). The base metal-rich bands exhibit a mylonitic texture, defined by chalcopyrite, sphalerite and galena wrapping around pyrite and/or country-rock porphyroclasts (Figs. 12b and 13a and b). These bands may represent shear zones that have contributed to internal imbrication and thickening of the orebody. Sigmoidal millimetre-thick lenses of granoblastic base metal sulphides and quartz within these shear zones, locally show en-échelon arrangement, and are interpreted as tension gashes or pullaparts infilled by minerals mobilised from pressure dissolution within the massive pyritite and also from within the shear zones (Fig. 13a). The latter interpretation requires the existence of a fluid phase during deformation.

In summary, massive pyritite had a brittle behaviour during its post-depositional tectonic deformation whereas the base metal sulphides were ductile, which is compatible with the low to very low metamorphic grade recorded in the region during the Variscan orogeny (up to $300^{\circ} \mathrm{C} / 2 \mathrm{~kb}$, Munhá 1990; locally up to $3 \mathrm{~kb}$, Marignac et al. 2003). At the scale of a single massive sulphide lens, during transpressional deformation, strain may have been focused into a basal less competent base metal-rich part of the 
Fig 11 Transmitted light $(\mathbf{a}-\mathbf{c})$ and reflected light $(\mathbf{d}-\mathbf{f})$ photomicrographs (all PPL, except c crossed polars; scale bar $1 \mathrm{~mm}$ ) of selected core sections from the A 3 borehole, Masa Valverde Deposit. a Culm phyllonite. b VSC ultramylonite on top of the massive sulphide body, comprising sparse silica micronodules in a phyllosilicate matrix. c Mylonitic chloritite with transposed pyrite veinlets (black), the latter showing brittle behaviour and pressure shadows. d Brecciated metapyritite, with carbonate cement (top of the massive sulphide body). e Oil immersion: relic collomorph textures, with delicately intergrown pyrite and chalcopyrite (minor galena, sphalerite and silicates), perfectly preserved from deformation inside the $90 \mathrm{~m}$ thick, rigid massive pyritic body. f Oil immersion: massive pyrite (white), with a network of cracks healed by mobilised chalcopyrite (yellow), brecciated and cemented by stockwork silicates (black)
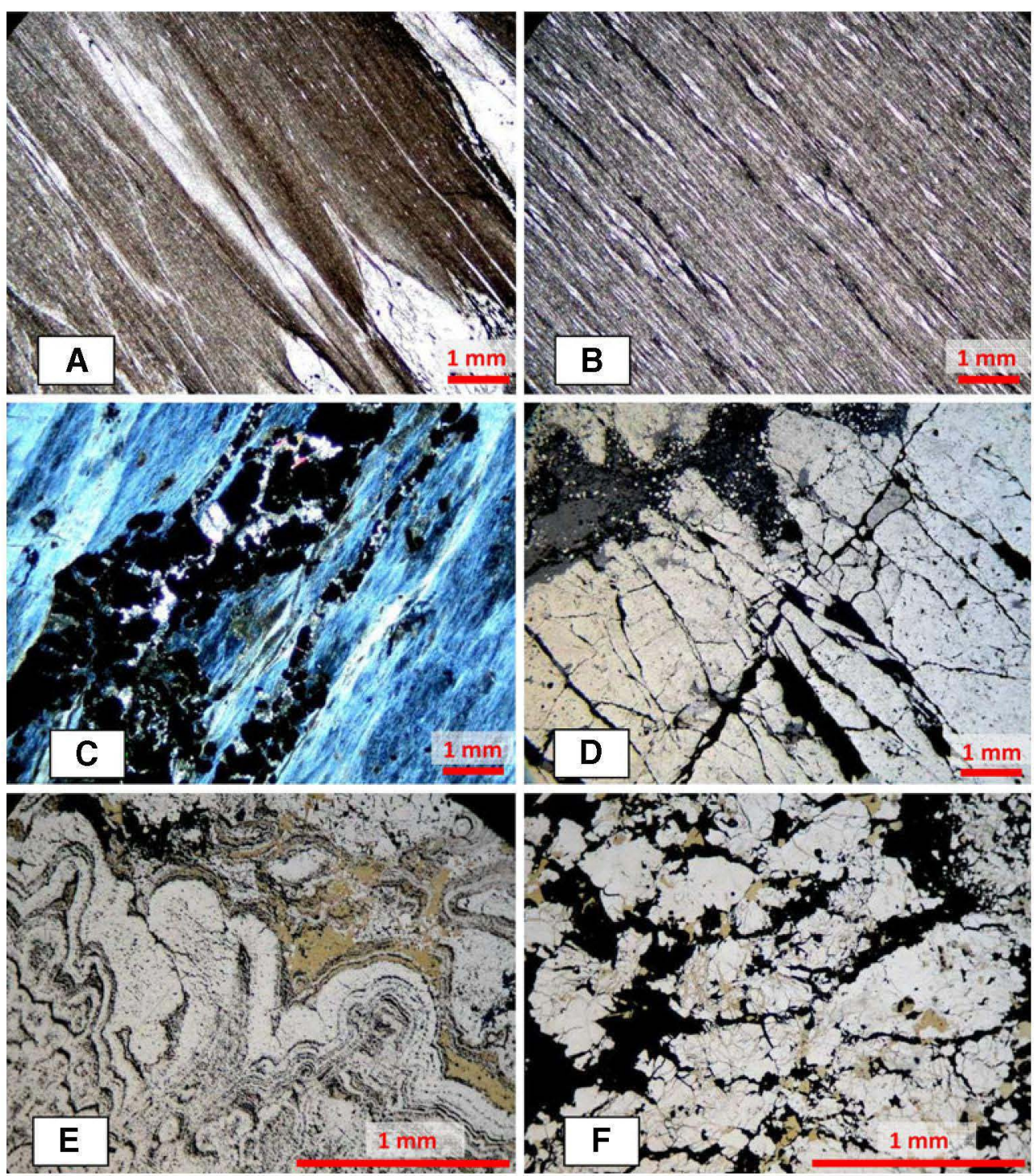

original lens, allowing it to detach from its sole. Subsequent transport along the basal detachment may have been eventually impeded by the presence of a mechanical barrier, against which a ramp would have nucleated allowing for the growth of a duplex by multiple stacking of ore horses rooted in the original basal décollement (Figs. 5, 12 and 13). Apart from tectonic thickening and the resulting accumulation of tonnage, this process may have also changed the base metal grade distribution in the deposit, resulting in higher grades in some areas and lower in other areas.

At a larger scale, the structural stacking of massive orebodies, stockwork, altered rocks and less altered country rocks is interpreted in the same way, i.e. in connection with pre-existing anisotropies and rheology differences (see Tornos et al. 1998, for a detailed description of the Filón Norte orebody, Tharsis, which is one of the best documented examples). The same style of tectonic thickening is also interpreted to occur at the regional scale (fractal geometry; compare the geometries of the structures imaged in Figs. 5, 12 and 13) and is held responsible for the present-day structure in the IPB, an example of inversion tectonics but exposed at a deeper level than the best known examples elsewhere.

\section{VMS deposits in NW Iberia}

The VMS deposits in NW Iberia (Santiago de Compostela and Moeche districts, Coruña Province, Galicia) occur in the Cabo Ortegal and Órdenes allochthonous complexes (Fig. 2) and are now exhausted. They were sea floor exhalative deposits in the Palaeozoic ophiolites (Badham and Williams 1981; Williams 1983a, b; Castroviejo 2002; Castroviejo et al. 2004a, 2006) and were affected by largescale tectonic transport. All these deposits were strongly deformed and metamorphosed at various crustal levels (low to medium grade, greenschist to amphibolite metamorphic 
facies), but they are much smaller than the giant deposits of the IPB. Despite their genetic and size differences, they make useful comparisons to build an understanding of the behaviour of VMS deposits under different tectonic conditions. The very complex Galician geology is now understood in the framework of Variscan collisional tectonics and metamorphism (e. g. Arenas et al. 1986, 2007; Gil Ibarguchi and Arenas 1990; Iglesias et al. 1983; Martínez Catalán et al. 1997, 1999, among others). ESE thrusting of various allochthonous terranes onto the Iberian Autochthon and the Parautochthon of the Galicia-Trás os Montes Zone (Figs. 1 and 2) was widespread. An outline of the NW Iberian geology can be found in Arenas et al. (2007), whereas the metallogeny of the Galician ophiolites and related units, including the VMS deposits, is summarised by Castroviejo et al. (2004b).

\section{Moeche district (Cabo Ortegal Complex)}

The Cabo Ortegal Complex (COC, Figs. 2 and 14) comprises various terranes of different ages with contrasting lithologies and metamorphic grades (Arenas 1991). Among them, the Purrido Amphibolite Unit (or Pena Escrita Unit, Fig. 14) has been interpreted as the only example of a Mesoproterozoic ophiolite $(1159 \pm 39 \mathrm{Ma})$ in the European Variscan Belt (Sánchez Martínez et al. 2006). The massive sulphide deposits occur in the Lower-Middle Ordovician ${ }^{2}$ Moeche Unit, also understood to be part of a dismembered ophiolite, sandwiched between the Pena Escrita and the Upper COC units, and the Iberian Autochthon (Silurian and Devonian very low- to low-grade metasediments). As shown in section $\mathrm{AB}$, Fig. 14, the Espasante-Moeche Group (comprising the Moeche Unit and the Somozas Mélange) is bound by two important thrusts separating it from the mylonitic metasediments of the Iberian Autochthon (below) and from the Pena Escrita Unit (above). Mining activity ceased in the area by the end of the 1960s, and some of the mines can no longer be visited. Those that have been studied are located in Fig. 14: the Piquito II, Barqueira and Maruxa mines and the Barbelas occurrences.

The rocks of the Moeche Unit show evidence of a pervasive ductile deformation, locally including mylonite or ultramylonite textures. Nevertheless, the distinction of rock types and interpretation of protoliths is still possible. The most distinct structural feature is a penetrative NNE-SSW schistosity $\left(\mathrm{S}_{1}\right)$, gently dipping to the west, related to the second phase of Variscan deformation and to the southeastwards thrusting of the nappes. Original contacts are entirely transposed in most cases, so that bedding and other contacts, including crosscutting feeder veinlets, are sub-

\footnotetext{
${ }^{2}$ More data and discussion of Geochronology in: Dallmeyer et al. 1997; Arenas et al. 2007; Castroviejo et al. 2006.
}

parallel to $S_{1}$. All of them may be locally folded by a third phase of deformation.

The Moeche Unit comprises chlorite schists (1 in Fig. 14), with interlayered metasedimentary rocks (mainly phyllites, sandy phyllites and phyllonites; 2 in Fig. 14) and quartz-pyrite-chlorite schists (3 in Fig. 14). The main lithology is mostly composed of chlorite, albite, quartz, amphibole (actinolite, relic hornblende), and accessory titanite, magnetite and pyrite. It is largely greenschist facies metabasite, in which some remnants of felsic dykes or sills can occasionally be found. The PT conditions of regional metamorphism, coeval with thrusting, have been estimated at $\sim 2-2.5 \mathrm{~kb}$ and $325-350^{\circ} \mathrm{C}$ (Castroviejo et al. 2006), very close to those prevailing in the IPB (Munhá 1990). The temperature was roughly similar to that of the earlier seafloor metamorphism. The high T/high $\mathrm{P}$ metamorphic conditions found in the overlying rocks of the Cabo Ortegal Complex have not been demonstrated in the Moeche Unit.

The metasedimentary rocks contain sand-size detrital albite grains whose source may be the volcanic rocks. The quartz-pyrite chlorite schists are the main host to the VMS ores and show a close spatial association to the deposits. This can be appreciated in the Barqueira mine (see map, Fig. 14) and in the underground geology of the Piquito II mine (Fig. 15), but it is not always seen in surface outcrops due to deformation and thrusting. The rock sequence in the Piquito II mine is upside down: the pervasively altered feeder zone lies on top of the sulphide layer and the unaltered sedimentary cover rocks are below. The sketch at the left in Fig. 15 shows the assumed original stratigraphy. The quartz-pyrite chlorite schists are thought to represent the footwall alteration to the massive sulphide ores, which form lens-shaped or stratiform bodies, most of which are stretched and thinned by deformation (Fig. 15).

The Moeche deposits are small, as is typical of modern seafloor analogues (Herzig and Hannington 1995). None of these deposits reach $1 \mathrm{Mt}$ reserves in spite of several exploration campaigns. Bulk grades reach $1.65 \% \mathrm{Cu}$ in the massive sulphide layer (Piquito II). The ores are characterised by $\mathrm{Zn} /(\mathrm{Zn}+\mathrm{Pb})$ values of 0.9 to $0.95, \mathrm{Cu} /$ $(\mathrm{Cu}+\mathrm{Zn}$ ) values $>0.9$ (up to 0.99 ) and $\mathrm{Au} / \mathrm{Ag}$ values of 2 to $5.3 \times 10^{-2}$ (mean $3 \times 10^{-2}$ ) (Castroviejo et al. 2004a). The $\mathrm{Zn} /(\mathrm{Zn}+\mathrm{Pb})$ ratios, as well as the relatively high $\mathrm{Au} /$ $\mathrm{Ag}$ ratios, suggest that the deposits belong to the $\mathrm{Cu}-\mathrm{Zn}$ class (Lydon 1992), while the high $\mathrm{Cu} /(\mathrm{Cu}+\mathrm{Zn})$ ratios are consistent with an ophiolitic affiliation (Troodos, Cyprus or Cu-type, Hutchinson 1973) within that class, in contrast to the $\mathrm{Zn}-\mathrm{Pb}-\mathrm{Cu}$ type of the IPB deposits.

The Moeche deposits share a rather simple mineralogy: pyrite and chalcopyrite, with subordinate sphalerite, and minor pyrrhotite, galena and secondary marcasite; magnetite and hematite may be abundant in the Maruxa mine, forming granoblastic and decussate aggregates, partly 

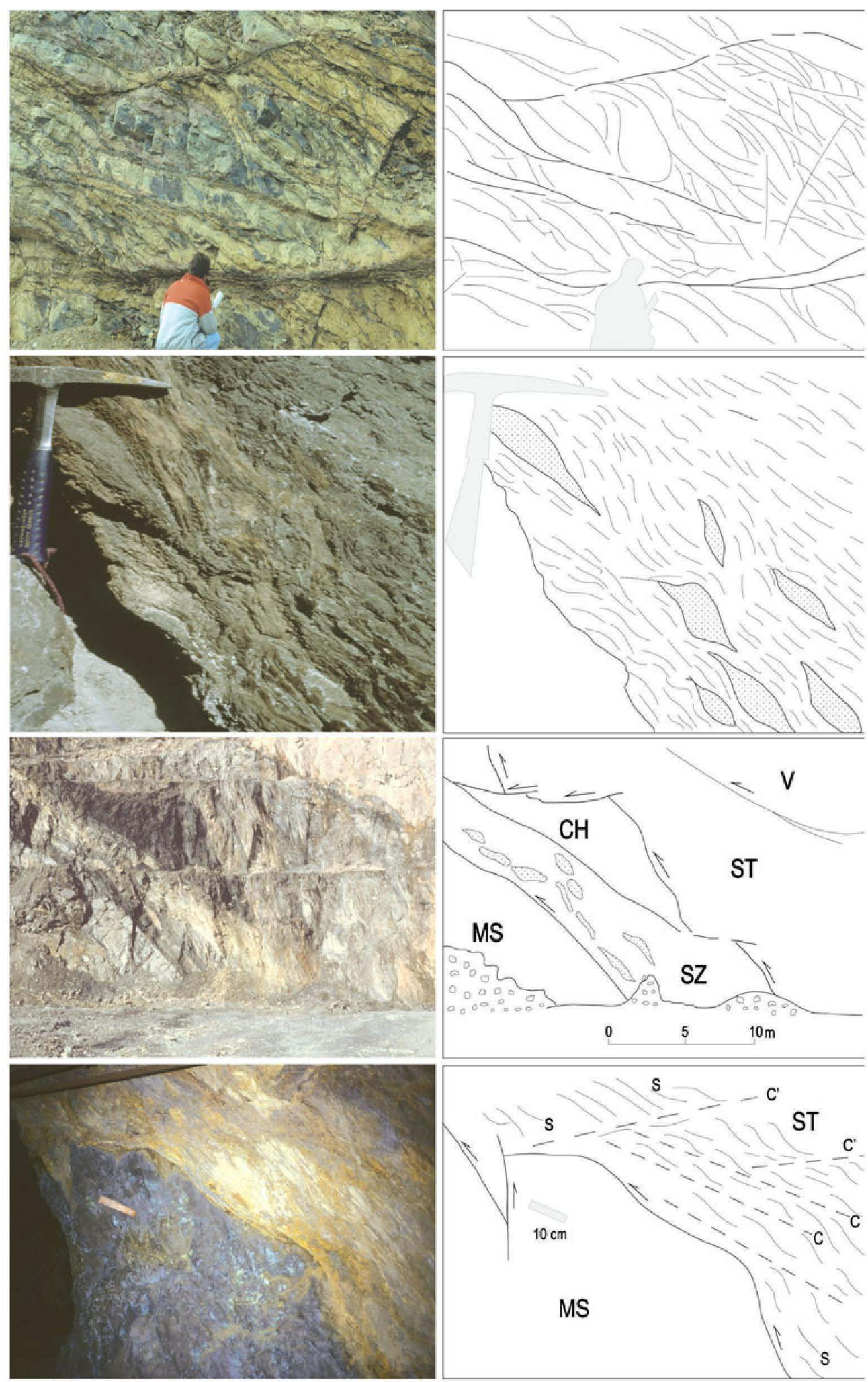

replaced by chalcopyrite. Traces of mackinawite, linneite, native gold/electrum (and PGE detected in the Barqueira mine) are found locally (also variable amounts of secondary covellite, limonite, chalcocite, and copper oxides and carbonates). The ores can be locally very rich: the values for modal content of chalcopyrite measured by digital image analysis on polished sections from samples of the Piquito II mine are $11.7 \%$ to $26.2 \%$ chalcopyrite, 
Fig. 12 Outcrop scale structures affecting orebodies in the IPB (a line-drawing of each picture is provided). a Extremely imbricated duplex structure deforming stockwork mineralization (Filón Sur mine, Tharsis). The stockwork veins inclined with respect to the maximum compressive axis of the strain ellipsoid were reactivated as thrusts whereas those at low angles were folded (not shown in this picture). The structure shows top to the right (south) kinematics and the picture corresponds to part of the forelimb of a large antiformal stack at the core of which the Filón Sur massive sulphide horse is thrust on top of the stockwork shown in the picture. b Ductile shear zone affecting base metal-rich massive sulphides and showing a $\mathrm{S}-\mathrm{C}$ structure; please notice the centimetre scale, internally massive sigmoidal lenses (porphyroclasts) of pyritite (Filón Norte mine, Tharsis). c Partial view of a duplex structure bringing carbonatized mafic volcanic rocks (V) on top of stockwork mineralization $(S T)$, in turn thrust onto massive sulphides $(M S)$. Note presence of a 3-5 m thick ductile shear zone $(S Z)$ between the two latter thrust sheets, in which decimetre to metre scale massive sulphide lithoclasts are embedded in a sericitized filonite developed by mylonitisation of the stockwork sheet. A triangular body of chloritized stockwork $(\mathrm{CH})$ remains isolated on top of the ductile shear zone. (Top of the San Guillermo ore lens, Filón Norte mine, Tharsis). The image corresponds to the topmost imbricates of a huge duplex, which incorporates up to seven massive sulphide sheets tectonically interleaved with stockwork ore sheets, described in great detail by Tornos et al. (1998). d Flat-and-ramp geometry of a mesoscopic-scale brittle thrust cut by a second order out-of-sequence thrust; the main thrust brings ductile stockwork with a beautiful S-C-C' structure on top of massive sulphide mineralization (La Zarza deep mine)

with roughly $50 \%$ pyrite. This made small-scale mining possible.

A common feature of all the deposits is the strong dynamometamorphic overprint, affecting the ores and the host rocks in distinctive ways (Castroviejo et al. 2004a). Chalcopyrite shows ductile behaviour, while sphalerite and pyrite remained in their brittle realm but are intensively affected by pressure solution and by small-scale solution transfer. The chlorite schists, both in host rocks and in the stockwork, show ductile deformation, in contrast with the massive sulphide layers, which remained rigid, although comminution by intense brecciation led locally to cataclastic flow. The result is the general flattening of the orebodies and the stretching and thinning of the massive sulphide layers, whose aspect ratios are very high ( 275:1 in the Maruxa mine, up to at least 1,000:1 in the Piquito II mine: see Fig. 15). These aspect ratios are very striking compared with the usually low aspect values found in present day analogues (e.g. ocean rift or seafloor VMS accumulations, Humphris et al. 1995) and are entirely due to post-depositional tectonic modification. Another effect of the deformation is folding, as seen in the Barqueira mine where the massive sulphide body is nearly vertical (3rd Variscan phase of deformation).

\section{Santiago district (Órdenes Complex)}

The deposits of Arinteiro, Bama, Fornás and Manoca are hosted by the Santiago Metabasite Unit in the Órdenes
Complex, near Santiago de Compostela (Figs. 2 and 16). These deposits have been characterised as metamorphosed ophiolitic VMS deposits (Badham and Williams 1981; Williams $1983 \mathrm{a}, \mathrm{b})$ and can be classified as $\mathrm{Cu}$ - or mafic type (Hutchinson 1973; Barrie and Hannington 1999) or $\mathrm{Cu}-\mathrm{Zn}$ type (Lydon 1992). This is also in agreement with the predominant silicate assemblages found in the Arinteiro host rocks (garnet-gedrite-biotite-staurolite), interpreted as the metamorphic equivalents of Fe-rich hydrothermally altered mafic rocks (Williams 1983a).

The VMS deposits are strongly deformed and folded and show a lens-shaped elongate morphology, exemplified by Arinteiro (Fig. 17). At Arinteiro, the sulphide ores mainly comprise pyrrhotite, chalcopyrite, pyrite and minor sphalerite disseminated in the metabasites. The "ore horizon" is interpreted as a stockwork deposit in which the present shape is due to strong flattening. Any initially crosscutting structures have been transposed, as in the Moeche deposits. The massive sulphide layer found in the Moeche deposits is missing in Arinteiro, although the sulphide-rich siliceous or calc-silicate marginal zone of the orebody may represent original syn-sedimentary chemical precipitates (Williams 1983a). However, small massive sulphide bodies (pyrrhotite, pyrite, chalcopyrite and sphalerite) occur at the Fornás and Manoca deposits (Fig. 16) and are interpreted as metamorphosed synsedimentary massive sulphide layers.

The Santiago deposits differ markedly from the Moeche deposits in size and metamorphic grade but share similar features such as allochthonous, metabasite-related setting and $\mathrm{Cu}$ or $\mathrm{Cu}-\mathrm{Zn}$ (ophiolitic) composition. Although larger than the Moeche deposits, tonnages from 1 Mt (Fornás, 1$2 \% \mathrm{Cu}$ ), through $12 \mathrm{Mt}$ (Arinteiro, $0.7 \% \mathrm{Cu}$ ) to $20 \mathrm{Mt}$ (Bama, 0.5\% Cu) are small compared to the giant deposits of the IPB. They are polymetamorphic deposits, reaching the amphibolite facies, with baric peak at $8 \mathrm{~kb} / 525^{\circ} \mathrm{C}$ and thermal peak at $6.5 \mathrm{~kb} / 575^{\circ} \mathrm{C}$ (Castiñeiras et al. 2000) or higher, in clear contrast to the low metamorphic grade of the Moeche deposits. This is reflected in the mineralogical composition of the Santiago orebodies, which are rich in pyrrhotite (coexisting with pyrite and chalcopyrite) and comprise unequivocal metamorphic minerals (e.g. zincian staurolite or gahnite, Williams 1983b), and it is also seen in their coarser crystalloblastic textures, although cataclasis associated with late events at greenschist facies may be important. Williams (1983a) argued that secondary concentration of sulphides during these late events was the most important control of $\mathrm{Cu}$ distribution in the Arinteiro-Bama ore horizon.

To summarise, the NW Iberian $\mathrm{Cu}$ sulphide orebodies are metamorphosed mafic-related VMS deposits of the $\mathrm{Cu}-$ $\mathrm{Zn}$ or ophiolitic type and were strongly deformed and transposed during the Variscan collision. Their size, 

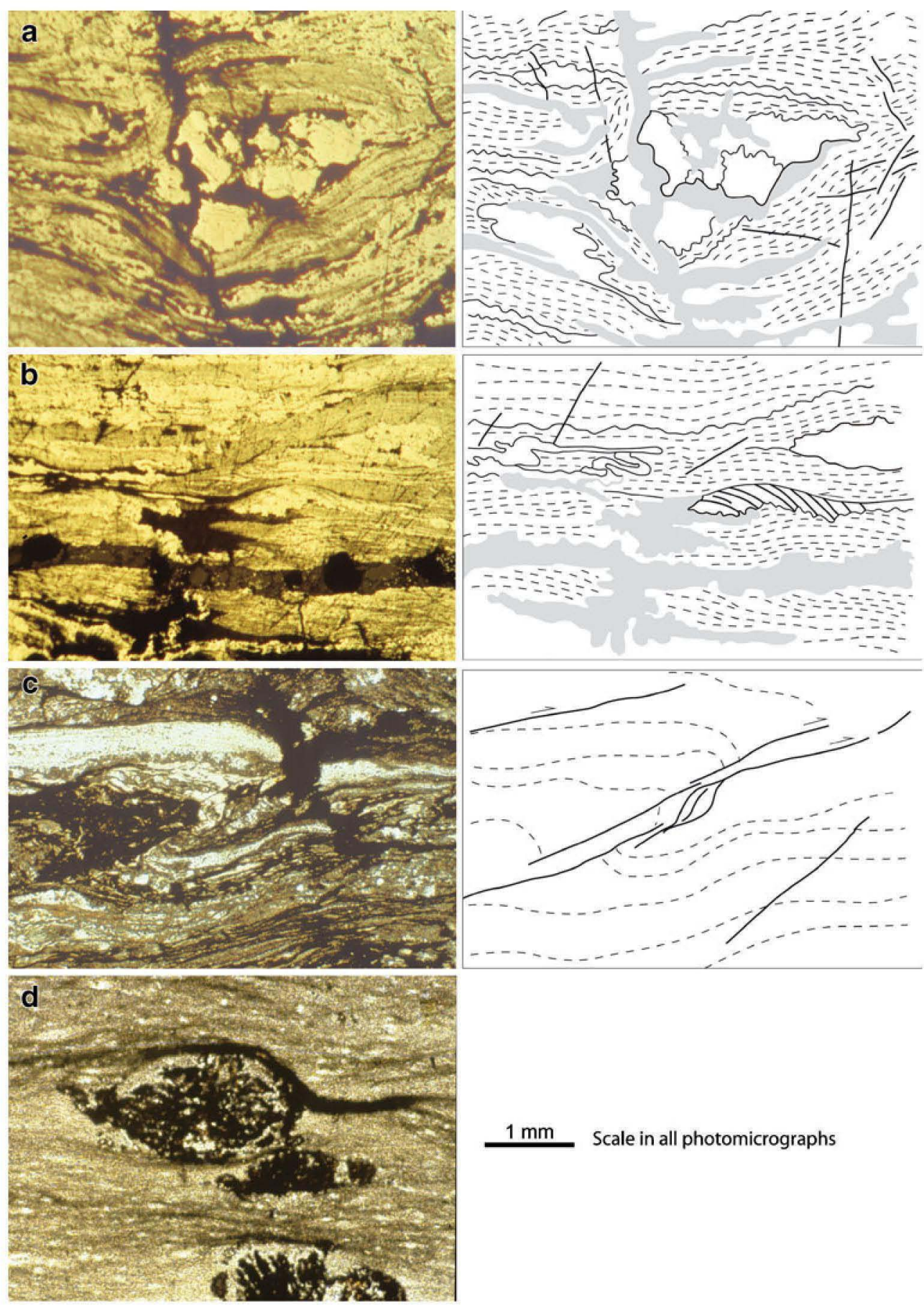

$1 \mathrm{~mm}$

Scale in all photomicrographs

Fig. 13 Microscopic scale structures affecting orebodies in the IPB; a line-drawing of each picture is provided ( $\mathbf{a}, \mathbf{b}$ reflected-light photomicrographs on polished sections; $\mathbf{c}, \mathbf{d}$ transmitted-light photomicrographs on thin-sections; all samples from the Tharsis district). a Sigmoidal shape pyritite clast wrapped by mylonitic, base metal-rich ductile sulphides. Note at least two different sets of pressure solution seams (solid lines in the sketch) and a prominent (blasto)mylonitic foliation (dashed lines in the sketch). The pressure solution fabrics collectively demonstrate the existence of a late stage dominated by flattening processes in the deformation of the IPB sulphide deposits. Grey shading represents the transparent minerals infill of late fractures or residual minerals accumulated at pressure solution seams. b Sigmoidal shape pyritite clasts wrapped by mylonitic, base metal-

rich ductile sulphides. As in a, there exists at least two different sets of pressure solution seams and a prominent (blasto)mylonitic foliation The penetrative mylonitic foliation in this case is axial planar to intrafolial, asymmetric isoclinal folds affecting some thin pyritite seams. The fine-grained texture of the pyritite clasts suggests that they are disrupted fragments of primary pyrite rich layers within a banded ore. Symbols in the line-drawing sketch as in a. c Millimetre scale fault propagation fold in phyllonitized chloritite (compare the geometry of this microstructure with the regional scale ones shown in Fig. 5). Dashed lines in sketch represent bedding plus compaction cleavage. d Sigma-shape pyrite porphyroclasts embedded in blastomylonitic chloritite 
Fig. 14 Geological map of the Espasante-Moeche area, Coruña Province, NW Spain, with location of the Moeche VMS deposits (Piquito I and II, Barqueira, Maruxa, and the Barbelas occurrence). See regional scheme in Fig. 2

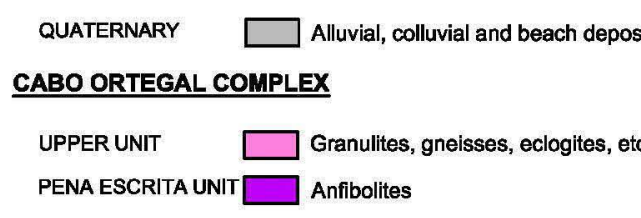

ESPASANTE - MOECHE GROUP
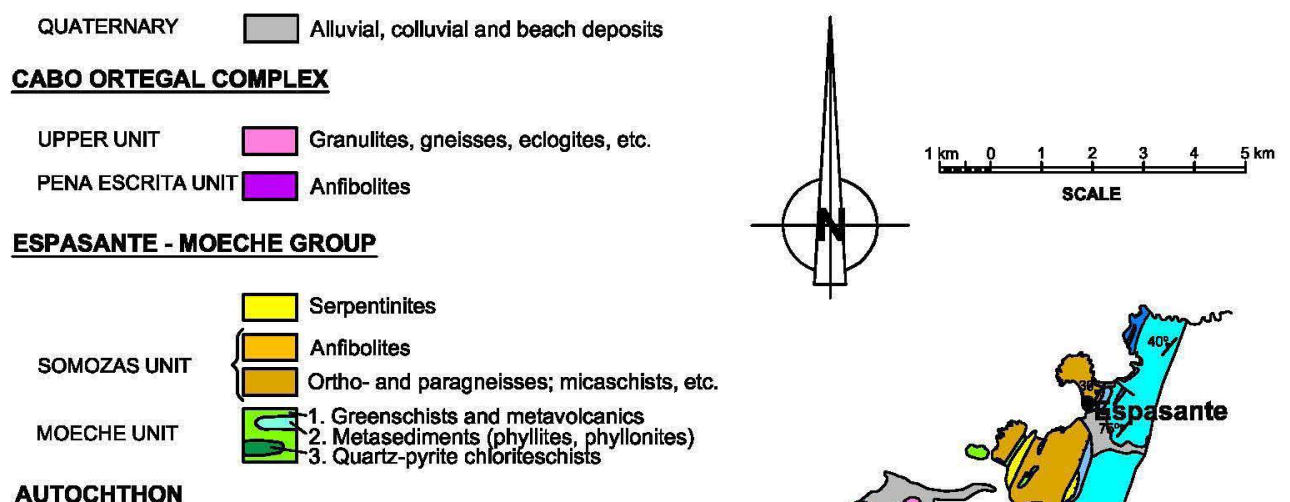

AUTOCHTHON

SILURIAN-DEVONIAN

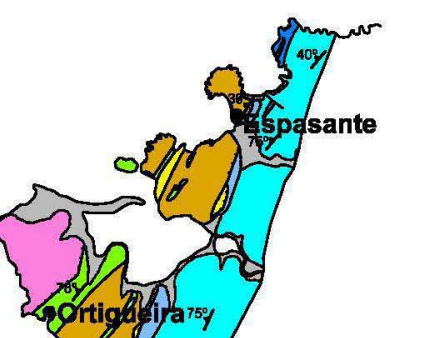

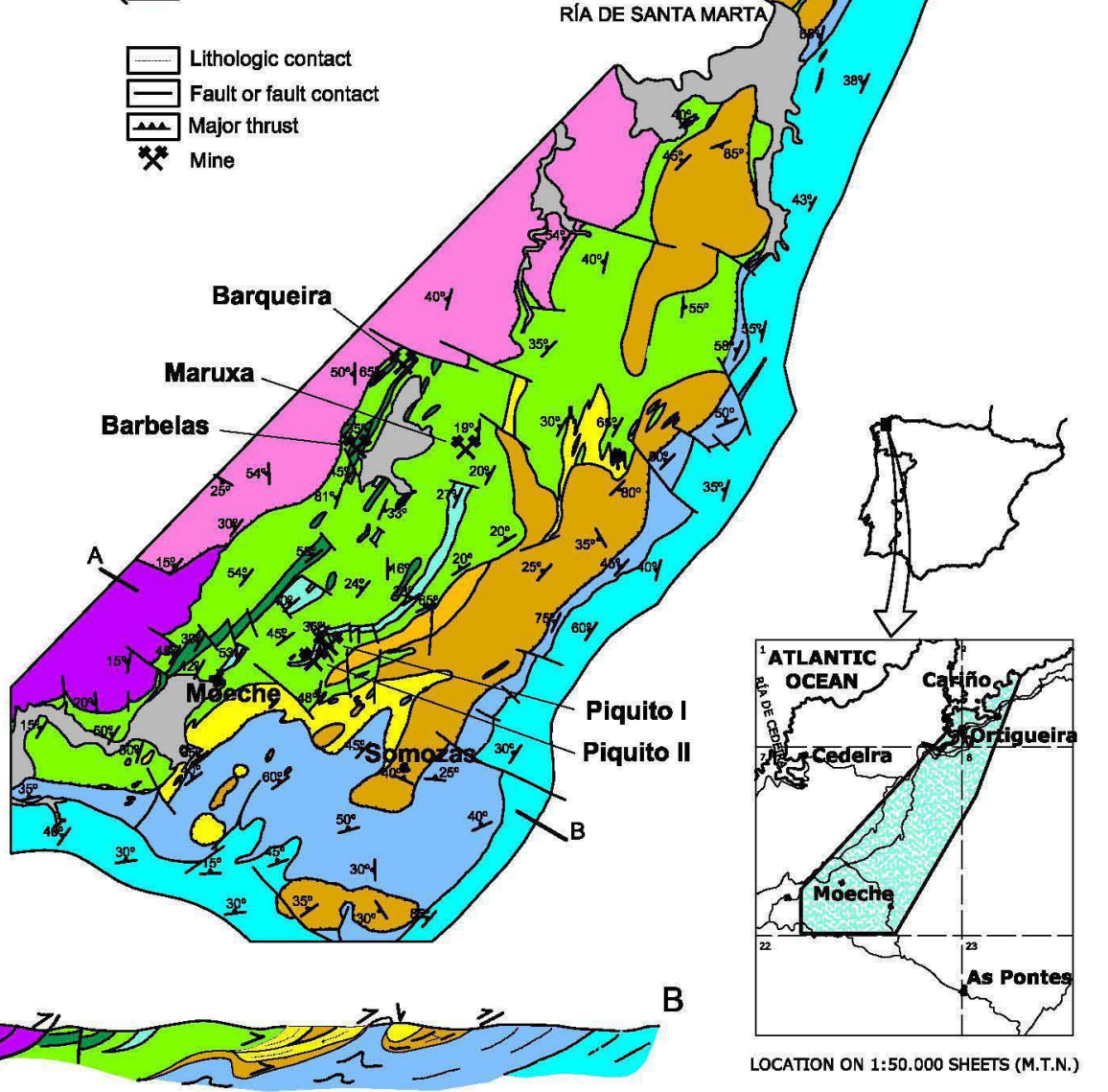

SECTION A - B

metamorphic grade, deformation style and final morphology differ in the Cabo Ortegal and Santiago districts: smaller size, lower metamorphic grade and higher aspect ratio in Cabo Ortegal, whereas the deformation style is more varied in the Santiago deposits, starting with amphibolite facies ductile deformation and recrystallization and finishing with a brittle stage during retrograde greenschist facies metamorphism. Metamorphic mobilisation of sulphides is observed in both districts, but none of the deposits have increased reserves due to tectonic stacking as described for the IPB.

Discussion: tectonic modification of VMS deposits as shown by Iberian examples

Post-depositional tectonic modification of VMS deposits had very different results in the IPB compared to the COC and OC 
Fig. 15 Geological profile along some galleries of the Piquito II mine, Coruña Province, NW Spain, showing the extremely thinned massive sulphide layer and the pyrite-chlorite schists comprising the stockwork, in a reverse stratigraphic sequence (modified from Castroviejo et al. 2004a, b)

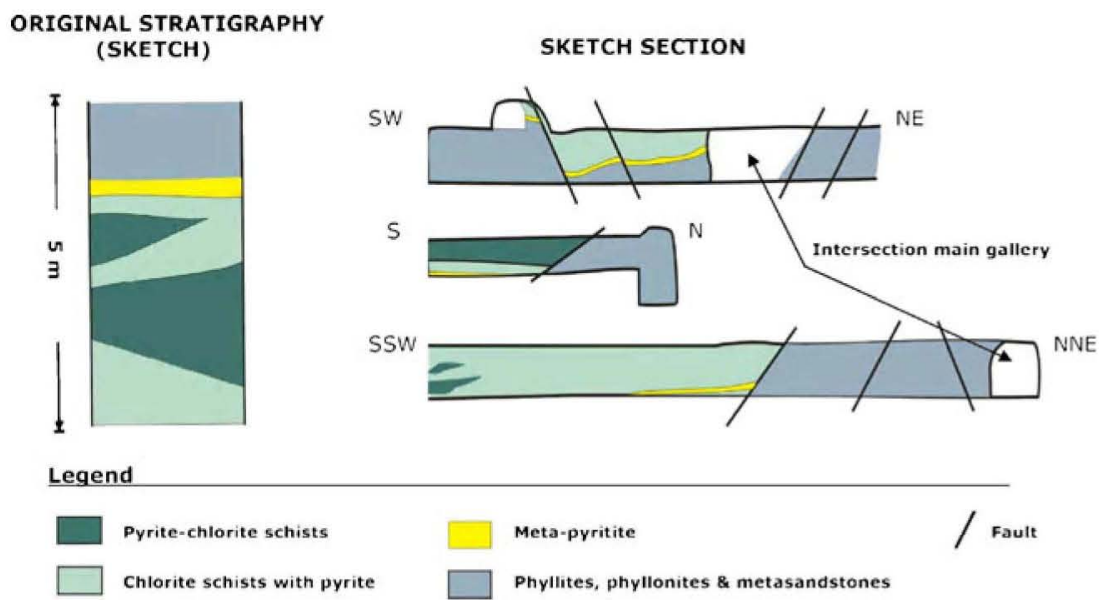

in NW Iberia. This has obvious economic implications for the total tonnage accumulated and for exploration. In the IPB, total tonnage at single sites has been increased by accumulation of different bodies (massive sulphide layers, mounds and stockwork lenses) transported and stacked upon each other, so that a thicker orebody was produced. This process of tectonic stacking was influenced by the size of the body, the style of deformation, the nature of the host rocks, and the metamorphic conditions during deformation. No tectonic stacking occurred in the COC and OC deposits, and the following discussion aims at explaining this different behaviour and finding criteria applicable to other VMS provinces.

What is common to all three Iberian VMS districts is the presence of an important dynamic metamorphism associat-

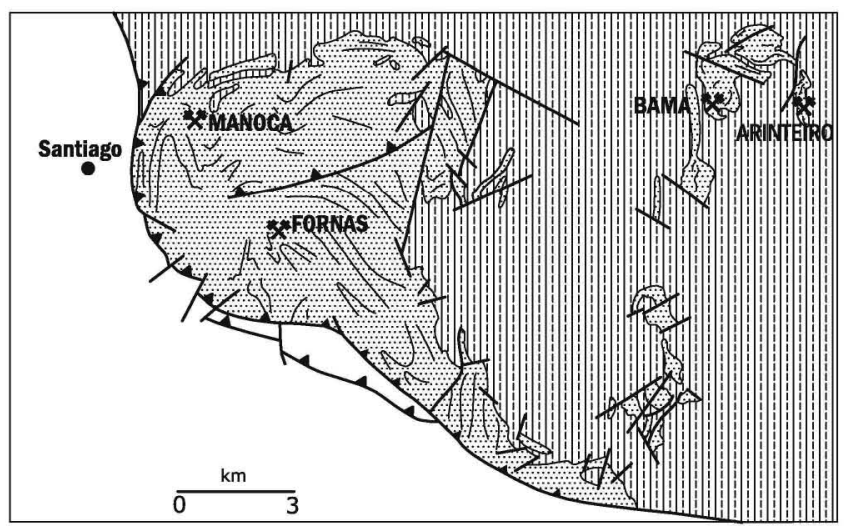

\section{ÓRDENES COMPLEX}

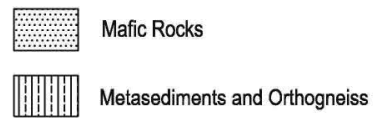

PARA-AUTOCHTHON

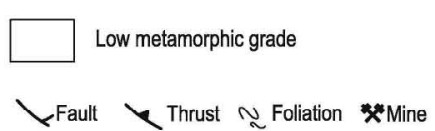

Fig. 16 Sketch geology of the Santiago metabasites, Órdenes Complex, Coruña Province, NW Spain, with location of the main VMS deposits (modified from Williams 1983a). See regional scheme in Fig. 2 ed with Variscan collisional tectonics at the periphery of the Iberian Massif. They differ from each other in many other aspects, and the analysis of those differences should explain the differential behaviour. The five aspects summarised in Table 2 may be important.

Deposit size The original (pre-deformation) deposit size seems to be a critical aspect. Larger deposits, if transported in response to contraction tectonics, are more likely to drag on their way and to collide with potential obstacles.

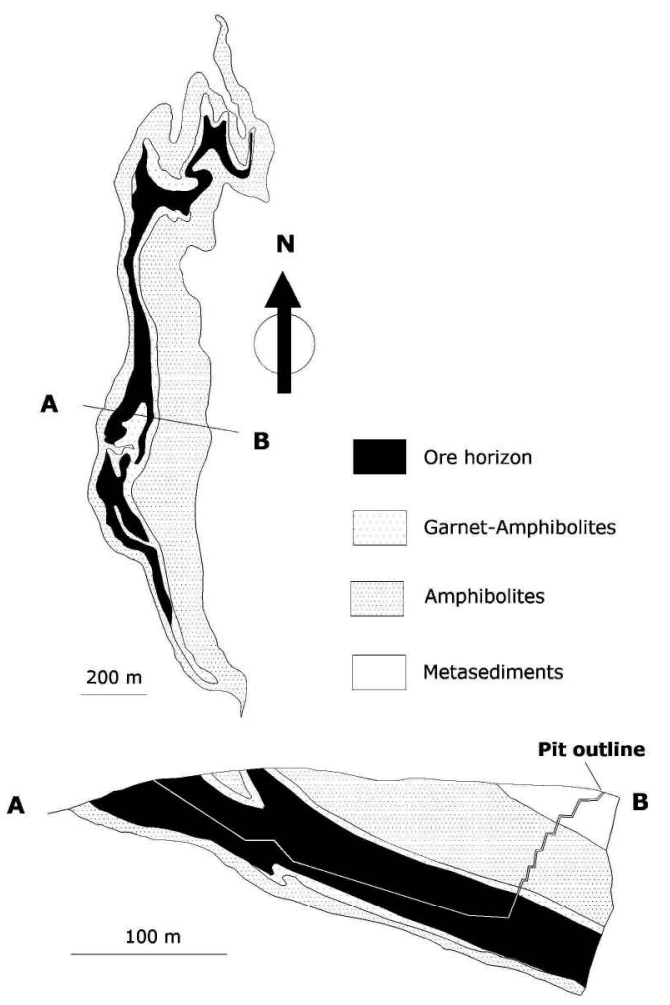

Fig. 17 Sketch map and section of the Arinteiro deposit, Santiago, NW Spain (modified from Williams 1983a) 
Table 2 A comparison of Iberian VMS provinces: IPB and NW Iberia (Cabo Ortegal and Órdenes Complexes, Galicia)

$I P B$ Iberian Pyrite Belt, $C O C$ Cabo Ortegal Complex, $O C$ Ordenes Complex

\begin{tabular}{llll}
\hline Concept & IPB & COC & OC \\
\hline Deposit size & Large/giant & Small $(<1 \mathrm{Mt})$ & Medium $(\sim 10 \mathrm{Mt})$ \\
Metamorphic grade & Very low/low $(\leq \mathrm{Chlr}$. Z. $)$ & Low $($ Chlorite Zone $)$ & Medium (Amph. Facies) \\
Deformation style & Brittle & Brittle & Ductile and brittle \\
Secondary mobilisation & Variable & Minor & Important \\
Final geometry & Tectonic stacking & Extreme flattening & Folding and flattening \\
\hline
\end{tabular}

Consequently, they tend to stack and to grow to be a larger obstacle for the next body to stack on. This should apply particularly for the giant deposits of the IPB. In contrast, smaller deposits are more likely to avoid obstacles and to accommodate deformation by thinning and tectonic transposition, as is the case in the Moeche district.

Metamorphic grade The IPB and COC (Moeche) deposits attained a similar metamorphic grade, not exceeding the chlorite zone, with estimated $\mathrm{T}$ around $300^{\circ} \mathrm{C}$ (Munhá $1990)$ for the IPB, and slightly higher $\left(\sim 325^{\circ} \mathrm{C}\right.$, Castroviejo et al. 2004a, 2006) for the Moeche deposits. Pressures were moderate, generally estimated around $2 \mathrm{~kb}$ in both cases. Under these conditions, each ore mineral shows a specific response to stress. Galena and chalcopyrite (also sphalerite under higher PT conditions) may be ductile (Marshall and Gilligan 1987); however, pyrite (usually $>90 \%$ of the ore) behaves in a brittle manner (Cox et al. 1981; McClay and Ellis $1983 \mathrm{a}, \mathrm{b}$ ) and the phyllosilicate-rich, strongly altered, host rocks will yield plastically (Boyle et al. 1998; Castroviejo et al. 2004a). This produces a strong rheologic contrast between the massive sulphide lenses and the host rocks. This contrast is observed in both districts. However, it produces quite different results, probably due to the different overall tectonic regimes and history. Whereas in the COC deposits, tectonic transposition and thinning or cataclastic flow of the small size massive sulphide layers has occurred, the huge and rigid pyritite bodies of the IPB were unable to yield in the same way and became stacked. For example, the Piquito II deposit in the COC has a totally transposed morphology, in which the extremely thinned massive sulphide layers, with aspect ratios up to $1,000: 1$, lie absolutely parallel to the schistosity. The schistosity also overprints any remaining cross-cutting structure in the stockwork. In contrast, the massive sulphide and stockwork bodies of the Masa Valverde deposit in the IPB are not thinned but stacked on each other so that the total thickness of the deposit may be increased over $100 \%$ (or aspect ratio reduced to less than a half of the original value).

In contrast, the Santiago metabasites underwent higher grade, amphibolite facies, metamorphism, above the brittleductile transition for pyrite (Marshall and Gilligan 1987), and ductile behaviour prevailed. There were no strong rheologic contrasts, with the result that the main effect of deformation was folding and flattening, accompanied by tectonic transposition, which gave the stockwork a consistent and parallel lens-like shape. This was accompanied by syn-metamorphic recrystallisation and re-equilibration of the sulphides (e.g. transformation of pyrite to pyrrhotite). None of the conditions found in the IPB and in the COC deposits applies in this case, and no stacking has been observed. Instead, ore mobilisation related to a late phase of retrograde greenschist facies metamorphism coeval with brittle deformation caused a redistribution of the ores in the ore horizon (Williams 1983a), a process also described in the IPB and to a minor scale in the COC.

Deformation style The most important aspect of deformation style (brittle or ductile deformation) as related to metamorphic grade has been discussed above. Nevertheless, according to experimental results, the response to stress depends not only on $\mathrm{P}$ and $\mathrm{T}$ but also on the value of deviatoric stress, the strain rate and factors like the availability of fluids, the anisotropy and rock fabric, etc. As an example, it might be assumed from the deformation styles observed that the strain rate in the Moeche deposits was significantly lower than in the IPB, while the pervasive access of fluids was enhanced in the former. This could explain the almost total homogenization of lithologies in the main metallotect (chlorite schists), the simple composition of the mineralogy and the prevalence of solution transfer processes in Moeche (e.g. Piquito II, Castroviejo et al. 2004a). Furthermore, a higher strain rate could explain the secondary, syn-metamorphic mobilisation of ores in the IPB, favoured by focused fluid discharge through breccias and along small-scale extensional fractures and cracks within the shear zones, as in the late event of brittle deformation in Arinteiro, OC (Williams 1983a).

Secondary mobilisation Syn-metamorphic secondary mobilisation of sulphides can result in improved ore grade and has been observed in the three VMS provinces, although with widely differing significance. It is unimportant in the COC, except for the mobilisation of synorogenic gold \pm PGE (but only as minor occurrences, Castroviejo et al. 2004b), but it seems to have been extensive in the Arinteiro deposit, OC (Williams 1983a). Secondary mobilisation may be locally important in some of the deposits of the IPB, as 
at Aznalcóllar, Tharsis and Neves-Corvo (see above). Nevertheless, it does not change the overall reserves, as it involves rearrangement of already deposited metals. Nor does it change the orebody geometry, since in most cases the metals do not escape the limits of the orebody itself.

Final geometry The resulting ore body geometry can be summarised as follows: (1) a reduction of the final aspect ratio by tectonic stacking of large deposits in the IPB, leading to overthickened and less extensive orebodies; (2) a spectacular increase of the final aspect ratio due to extreme thinning and transposition of the small sulphide lenses in the COC deposits; (3) pronounced folding, flattening and transposition of the orebodies, without stacking, in the OC deposits.

Two implications follow from this discussion. First, lowgrade (up to greenschist facies) metamorphism and associated brittle deformation favour the construction of giant deposits by tectonic stacking, whereas higher metamorphic grades tend to preclude it, if the plastic domain for pyrite deformation is attained. Other processes such as secondary mobilisation can be of local importance. Second, these criteria can be used in mineral exploration, by selecting target areas in which favourable conditions occur for big VMS deposits: post-ore thrust-style tectonics, brittle conditions for pyrite, greenschist facies metamorphism. Some exploration methods can become particularly relevant, given the huge size of the sulphide masses to be detected. Among them, gravimetric exploration has already proved successful in the IPB but cannot succeed in identifying blind ore deposits against dense rocks, such as gabbros or metabasites. As an alternative, Geothermics (Gable et al. 1997a) has been successfully tested in the IPB as a new exploration tool for big VMS deposits.

The processes discussed for Iberia should also apply to other districts with similar tectonic and metamorphic histories. However, in most cases, only subordinate modifications of the original geometry have been attributed to thrust stacking, in spite of recognition of tightly folded and thrust geometries (e.g. Febrel 1966, 1971; Jenks 1971). Metamorphism and deformation of VMS deposits has received wide attention in the international literature, and its importance has also been established in many districts (e.g. Vokes and Craig 1993; Craig and Vokes 1993; Sulitjelma, Norway: Cook et al. 1993; Mobrun, Québec: Larocque and Hodgson 1995, among many others). The monographs by Spry et al. (2000) and Goodfellow et al. (2003) furnish a wealth of examples from different regions in the world and from the VMS deposits of the Bathurst Mining Camp (N. Brunswick and N. Maine), respectively, with useful discussions of deformation and of solution transfer and remobilisation.

Analysis of the conditions in each case should help understand the possible resulting geometries. As an example, two cases will be briefly discussed: the Howard Pass XY deposit, Yukon and the Heath Steele and Brunswick deposits, Bathurst. These deposits show intense deformation and widespread remobilisation, as the IPB deposits, but they show also some critical differences. In the first case (Jonasson and Goodfellow 1986), the onset of tectonic deformation occurred when the deposit was still water-saturated, and the deformation process enhanced early and very rapid dewatering and syn-diagenetic solution transfer. A zone of detachment is reported at the base of the deposit, but the main deformation occurred when the sediments were unconsolidated, i.e. ductile, thus precluding tectonic stacking, even if buckle folds with attenuated and sheared limbs and extensive decollement of basal sulphide beds are observed. In the second case (de Roo and van Staal 2003), remobilisation is explained by solution transfer (implying dissolution of pyrite from zones of high strain) and by ductile flow of incompetent sulphides, excess fluids leading to sulphide breccias formed in dilational jogs by fluid-assisted sulphide injection. Although no comparative study with the IPB deposits has been undertaken, the authors report several features that might explain the absence of tectonic stacking at the Heath Steele and Brunswick deposits. For example, the ductile behaviour of the sulphides, which are usually thinly banded and base-metal rich and are considered "generally incompetent with respect to their host rocks" or the absence of "major (kilometre scale) translation between footwall and hanging wall rocks". In both cases, the rheologic contrasts observed in the IPB were missing.

In other cases, stacking has been described as a primary feature of the deposit, resulting from successive cycles of mineralisation, as in the Millenbach deposit, Noranda, Quebec (Simmons 1973) or in the Wilga deposit, Victoria, Australia (Cox et al. 1990). This concept of stacking, reported by Large (1992) as typical of two Australian VHMS deposit styles (the cyclic zoned- and the stacked lenses-style deposits), must not be confused with the tectonic stacking discussed in this work, which is a post-depositional feature linked to deformation and tectonic transport.

\section{Conclusions}

Tectonic stacking can contribute to the tonnage of a VMS deposit, due to the accumulation at a single site of parts of an originally thinner, more extensive deposit, as shown by the Masa Valverde and many other deposits in the Iberian Pyrite Belt. Stacking results in lowering the final aspect ratio of the deposit.

Tectonic stacking is favoured by thin-skinned tectonics and by strong rheologic contrasts under low metamorphic grade conditions, implying a brittle regime for pyrite, as found in the Iberian Pyrite Belt. The higher grade 
metamorphic conditions found in the Santiago Amphibolites (Órdenes Complex, North West Iberia) preclude this process for the deposits (Arinteiro, Fornás, etc.), leading only to folding and flattening of the orebodies, coeval with metamorphic recrystallization and re-equilibration.

Size is also an important factor. Small deposits, such as those of the Moeche Unit (Cabo Ortegal Complex, NW Iberia) are not likely to stack and show tectonic transposition and strong thinning, without any increase in tonnage, in spite of low-grade metamorphic conditions comparable to those in the Iberian Pyrite Belt.

The examples of the Iberian Pyrite Belt suggest that a dramatic thickening by tectonic stacking is possible in the conditions described (big initial size of deposits, significant tectonic transport or thin-skinned tectonics, brittle realm for pyrite or low grade metamorphic conditions) and that it contributed to the giant and super-giant mine resources there, so enhancing the potential of new specific exploration methods (e.g. Geothermics).

Consequently, even though tectonic modification of VMS deposits can have very negative effects on their size and economic value, due to dislocation, thinning or dismemberment of the ore bodies, some of the processes discussed may also contribute in a positive way, as shown in the IPB. Analysis of metamorphic grade, structural criteria and regional tectonic studies following the approach shown here may be used to assist exploration in other VMS districts.

Acknowledgements This study has benefited from the authors work for the UE/Brite Euram Projects Innovative Geothermal Methodology to detect deep blind polymetallic orebodies (no. BE-8227-93, 1994/97, Contract BRE2-CT94-1027), and Development of a methodology for detecting deep metal ore deposits through physico-chemical analysis of fluids in shallow boreholes (no. BE96-3162, 1998/2000, contract BRPR-CT97-0374). Our co-workers in these projects are thankfully acknolewdged. L Sánchez, C León and H Romero (ETSI Minas, UPM), and $\mathrm{M}^{\mathrm{a}}$ José Torres Matilla (IGME) helped draft some figures. Chemical analyses were provided by EN Adaro. Other laboratory work for this paper was carried out in the Laboratorio de Microscopia Aplicada y Análisis de Imagen (rla 207) of the Madrid School of Mines, Universidad Politécnica de Madrid, with funding through the Laboratory Network of the Comunidad de Madrid (code UP0644) and through projects GR92-0135, UE95-0007, UE98-0027, and CGL2006-13688-C02-01. The thorough and insightful comments and suggestions from the reviewers, Ron Berry and Howard Poulsen, from the issue editor, Rodney Allen, and from the Editor-in-Chief of Miner Deposita, Patrick Williams, are sincerely acknowledged.

\section{References}

Almodóvar GR, Sáez R, Pons JM, Maestre A, Toscano M, Pascual E (1998) Geology and genesis of the Aznalcollar massive sulphide deposit, Iberian Pyrite Belt, Spain. Miner Deposita 33:111-136

Arenas R (1991) Opposite P, T, t paths of Hercynian metamorphism between the upper units of the Cabo Ortegal Complex and their substratum (NW of the Iberian Massif). Tectonophysics 191:347-394
Arenas R, Gil Ibarguchi JI, González Lodeiro F, Martínez Catalán JR, Ortega Gironés E, de Pablo Maciá JG, Peinado M (1986) Tectonostratigraphic units in the complexes with mafic and related rocks of the NW of the Iberian Massif. Hercynica 2:87-110

Arenas R, Martínez Catalán JR, Abati J, Sánchez Martínez S (eds) (2007) The rootless Variscan Suture of NW Iberia (Galicia, Spain). Publs. IGME, Madrid, 177 pp

Badham JPN, Williams PJ (1981) Genetic and exploration models for sulphide ores in metaophiolites, northwest Spain. Econ Geol 76:2118-2127

Barrie CT, Hannington MD (1999) Classification of volcanicassociated massive sulfide deposits based on host-rock composition. SEG Rev Econ Geol 8:1-11

Boyle AP, Prior DJ, Banham MH, Timms NE (1998) Plastic deformation of metamorphic pyrite: new evidence from electron-backscatter diffraction and forescatter orientationcontrast imaging. Miner Deposita 34:71-81

Castiñeiras P, Arenas R, Martínez Catalán JR, González del Tánago J (2000) Mineral assemblages and P-T constraints in Ky-St-Grt schists from the Arinteiro antiform (Órdenes Complex, NW Iberian Massif). In: Variscan-Appalachian dynamics: the building of the Upper Paleozoic basement. Basement Tectonics 15:81-84

Castroviejo R (2002) Genesis and metamorphism of Cyprus-type massive sulphide deposits during Hercynian collision, Cabo Ortegal Complex, NW Iberian Massif (Spain). Proc. 11th Quadrennial IAGOD Symp. and Geocongress 2002, Windhoek, Namibia, p 22 \& Ext Abs CD edition

Castroviejo R, Gable R, Cueto R, Foucher JC, Soler M, Gounot J, Batsale JC, López A, Joubert M (1996) Ensayo de una metodología innovadora para la detección de masas polimetálicas profundas: modelo geológico y exploración geotérmica preliminares de la Masa Valverde (Huelva). Bol Geol Min 107:485-509

Castroviejo R, Armstrong E, Lago A, Martínez Simón JM, Argüelles A (2004a) Geología de las Mineralizaciones de Sulfuros Masivos en los cloritoesquistos de Moeche (Complejo de Cabo Ortegal, La Coruña). Bol Geol Min 115:3-34

Castroviejo R, Moreno T, Prichard H, Fallick AE (2004b) Metalogenia de las ofiolitas de Galicia y unidades asociadas (NW del Macizo Ibérico, España). In: Pereira ES, Castroviejo R, Ortiz F (eds) Complejos Ofiolíticos en IBEROAMÉRICA: Guías de Prospección para Metales Preciosos, Proy XIII-1. CYTED, Madrid, pp 231-266. ISBN 84-96023-34-9

Castroviejo R, Tassinari C, Proenza J (2006) New data on the ophiolitic VMS deposits of Moeche (Cabo Ortegal Complex, NW Spain). Proc. 12th Quadrennial IAGOD Symp. 2006, Moscow, p 98 \& Ext Abs CD

Chauvet A, Onézime J, Charvet J, Barbanson L, Faure M (2004) Synto late-tectonic emplacement within the Spanish Section of the Iberian Pyrite Belt: structural, textural, and mineralogical constraints in the Tharsis and La Zarza areas. Econ Geol 99:1781-1792

Cook N, Halls C, Boyle AP (1993) Deformation and metamorphism of massive sulphides at Sulitjelma, Norway. Mineral Mag 57:67-81

Cox SF, Etheridge MA, Hobbs BE (1981) The experimental ductile deformation of polycrystalline and single crystal pyrite. Econ Geol 76:2105-2117

Cox R, Ebsworth GB, Forsythe DL (1990) The Wilga base-precious metal deposit, Benambra, Victoria, Australia. Terra Nova 2:262-270

Craig JR, Vokes FM (1993) The metamorphism of pyrite and pyritic ores: an overview. Mineral Mag 57:3-18

Dallmeyer RD, Martínez Catalán JR, Arenas R, Gil Ibarguchi J, Gutiérrez Alonso G, Farias P, Bastida F, Aller J (1997) Diachronous Variscan tectonothermal activity in the NW Iberian Massif: evidence from $40 \mathrm{Ar} / 39 \mathrm{Ar}$ dating of regional fabrics. Tectonophysics 277:307-337 
de Roo JA, van Staal CR (2003) Sulfide remobilisation and sulfide breccias in the Heath Steele and Brunswick Deposits, Bathurst Mining Camp, New Brunswick. Econ Geol Monogr 11:479-496

Doetsch J (1957) Esbozo geoquímico y mineralogenético del criadero de piritas "Las Herrerías", Puebla de Guzmán (Huelva). Bol IGME 68:227-306

Febrel T (1966) Hoja de Calañas $\left(n^{\circ}\right.$ 959) y Memoria explicativa, Mapa Geológico de España 1:50 000 ( $1^{\mathrm{a}}$ serie). IGME, Madrid, $28 \mathrm{pp}$ and map

Febrel T (1971) Yacimientos Minerales. ETSI Minas, Madrid, 187 pp

Gable R, Castroviejo R, Cueto R, Foucher JC, Batsale JC (1997a) Geothermics: a new BMS exploration tool. In: Papunen H (ed) Mineral deposits: research and exploration - where do they meet? Balkema, Rotterdam, pp 941-944

Gable R, Castroviejo R, Gounot J, Bonnemaison M (eds) (1997b) Innovative geothermal methodology to detect deep blind polymetallic orebodies. Synthesis report for publication (30 june 1997). BRITE EURAM Project BRE2-CT94-AO27, CE/DG XII, Brussels, Belgium, $35 \mathrm{p}$

Gable R, Castroviejo R, Cueto R, Batsale JC, Foucher JC, Soler M, Gounot J, Guerin G, López A (1998) Test of the geothermal method for deep polymetallic ore exploration in Masa Valverde (Huelva). Proc. IV Int. Symp. Polymetallic Sulphides of the Iberian Pyrite Belt. APIMINERAL, Lisbon, Portugal 18-21 January 1998, Comm A-14: 23 pp

Gil Ibarguchi JI, Arenas R (1990) Metamorphic evolution of the Allochthonous Complexes from the Northwest of the Iberian Peninsula. In: Dallmeyer RD, Martínez-García E (eds) PreMesozoic geology of Iberia. Springer-Verlag, pp 237-246

Goodfellow WD, McCutcheon SR, Peter JM (eds) (2003) Massive sulphide deposits of the Bathurst Mining Camp, New Brunswick and Northern Maine. Econ Geol Monogr 11, 930 pp

Herzig PM, Hannington MD (1995) Polymetallic massive sulfides at the modern seafloor. A review. Ore Geol Rev 10:95-115

Humphris SE, Herzig PM, Miller DJ, Alt JC, Becker K, Brown D, Brügmann $\mathrm{G}$, Chiba $\mathrm{H}$, Fouquet $\mathrm{Y}$, Gemmell JB, Guerin $\mathrm{G}$, Hannington MD, Holm NG, Honnorez JJ, Itturino GJ, Knott R, Ludwig R, Nakamura K, Petersen S, Reysenbach AL, Rona PA, Smith S, Sturz AA, Tivey MK, Zhao X (1995) The internal structure of an active sea-floor massive sulphide deposit. Nature 377:713-716

Hutchinson RW (1973) Volcanogenic sulphide deposits and their metallogenic significance. Econ Geol 68:1223-1246

Iglesias M, Ribeiro ML, Ribeiro A (1983) La interpretación aloctonista de la estructura del noroeste penínsular. In: Geología de España (Libro Jubilar J.M. Ríos), t. I, IGME, Madrid, pp 459-467

Jenks WF (1971) Tectonic transport of massive sulfide deposits in submarine volcanic and sedimentary host rocks. Econ Geol 66:1215-1224

Jonasson IR, Goodfellow WD (1986) Sedimentary and diagenetic textures, and deformation structures within the sulphide zone of the Howard Pass (XY) Zn-Pb deposit, Yukon and Northwest Territories. In: Morin JA (ed) Mineral Deposits of Northern Cordillera. Canad Inst Mining Metall, Spec 37:51-70

Laing WP (1977) Structural interpretation of drill core from folded and cleaved rocks. Econ Geol 72:671-685

Large R (1992) Australian volcanic-hosted massive sulfide deposits: features, styles, and genetic models. Econ Geol 87:471-510

Larocque ACL, Hodgson CJ (1995) Effects of greenschist-facies metamorphism and related deformation on the Mobrun massive sulphide deposit, Québec, Canada. Miner Deposita 30:439-448

Leistel JM, Marcoux E, Deschamps Y (1998a) Chert in the Iberian Pyrite Belt. Miner Deposita 33:59-81

Leistel JM, Marcoux E, Thiéblemont D, Quesada C, Sánchez A, Almodóvar GR, Pascual E, Sáez R (1998b) The volcanic-hosted massive sulphide deposits of the Iberian Pyrite Belt. Miner Deposita 33:2-30

Lydon JW (1992) Volcanogenic massive sulphide deposits. Part 1: a descriptive model. Geosc Can Repr Ser 3:145-153

Marignac C, Diagana B, Cathelineau M, Boiron MC, Banks D, Fourcade S, Vallance J (2003) Remobilisation of base metals and gold by Variscan metamorphic fluids in the soutyh Iberian pyrite belt: evidence from the Tharsis VMS deposit. Chem Geol 194:143-165

Marshall B, Gilligan LB (1987) An introduction to remobilisation: information from ore-body geometry and experimental considerations. Ore Geol Rev 2:87-131

Martínez Catalán JR, Arenas R, Díaz García F, Abati J (1997) Variscan accretionary complex of northwest Iberia: terrane correlation and succession of tectonothermal events. Geology 25(12):1103-1106

Martínez Catalán JR, Arenas R, Díaz García F, Abati J (1999) Allochthonous units in the Variscan belt of NW Iberia. In: AK Sinha (ed) Basement tectonics 13:65-68

Matte Ph (1986) Tectonics and plate tectonics model for the Variscan Belt of Europe. Tectonophysics 126:329-374

Matte Ph (1991) Accretionary history and crustal evolution of the Variscan Belt in Western Europe. Tectonophysics 196:309-337

Matte $\mathrm{Ph}$ (2001) The Variscan collage and orogeny (480-290 Ma) and the tectonic definition of the Armorica microplate: a review. Terra Nova 13:122-128

Matte Ph, Ribeiro A (1975) Forme et orientation de l'ellipsoïde de déformation dans la virgation hercynienne de Galicia: relation avec le plissement et hypothèses sur la genèse de l'arc ibéroarmoricain. CR Acad Sci Paris 280:2825-2828

McClay KR, Ellis PG (1983a) Deformation and recrystallization of pyrite. Mineral Mag 47:527-538

McClay KR, Ellis PG (1983b) Deformation of pyrite. Econ Geol $79: 400-403$

McKee GS (2001) Deformation and ore remobilisation within the Aguas Teñidas Este VMS deposit, Iberian Pyrite Belt. Trans Inst Min Metall 110:B50-B58

Munhá J (1990) Metamorphic evolution of the South Portuguese/Pulo do Lobo Zone. In: Dallmeyer RD, Martínez García E (eds) Premesozoic geology of Iberia. Springer, Berlin, pp 363-368

Munhá J, Oliveira JT, Ribeiro A, Oliveira V, Quesada C, Kerrich R (1986) Beja-Acebuches Ophiolite: characterisation and geodynamic significance. Bol Soc Geol Port 2:31

Ohashi R (1920) On the origin of the Kuroko of the Kosaka copper mines, northern Japan. Akita Min Coll J 2:11-18

Oliveira JT, Quesada C (1998) A comparison of stratigraphy, structure and paleogeography of the South Portuguese Zone and Southwest England, European Variscides. Annual Conf Ussher Soc 9:141-150

Oliveira JT, Horn M, Paproth E (1979) Preliminary note on the stratigraphy of the Baixo Alentejo Flysch group, Carboniferous of southern Portugal, and on the paleogeographic development compared to corresponding units in NW Germany. Comun Serv Geol Port 65:151-168

Oliveira JT, Pereira Z, Carvalho P, Pacheco N, Korn D (2004) Stratigraphy of the tectonically imbricated lithological succession of the Neves Corvo mine area, Iberian Pyrite Belt, Portugal. Miner Deposita 39:422-436

Pawels H, Tercier-Waeber ML, Arenas M, Castroviejo R, Deschamps Y, Lassin A, Graziottin F, Elorza FJ (2002) Chemical characteristics of groundwater around two massive sulphide deposits in an area of previous mining contamination, Iberian Pyrite Belt, Spain. J Geochem Explor 75:17-41

Quesada C (1991) Geological constraints on the Palaeozoic tectonic evolution of tectonostratigraphic terranes in the Iberian Massif Tectonophysics 185:225-245 
Quesada C (1992) Evolución tectónica del Macizo Ibérico: Una historia de crecimiento por acrecencia sucesiva de terrenos durante el Proterozoico superior y el Palaeozoico. In: Gutiérrez Marco JC, Saavedra J, Rábano I (eds) Palaeozoico inferior de Ibero-América. University of Extremadura, Mérida, pp 173-190

Quesada C (1996) Estructura del sector español de la Faja Pirítica: implicaciones para la exploración de yacimientos. Bol Geol Min 107:65-78

Quesada C (1998) A reappraisal of the structure of the Spanish segment of the Iberian Pyrite Belt. Miner Deposita 33:31-44

Quesada C, Bellido F, Dallmeyer RD, Gil Ibarguchi JI, Oliveira JT, Pérez Estaún A, Ribeiro A, Robardet M, Silva JB (1991) Terranes within the Iberian Massif: correlations with West African Sequences. In: Dallmeyer RD, Lécorché JP (eds) The West African orogens and circum-Atlantic correlations. Springer, Berlin, pp 267-293

Quesada C, Fonseca P, Munhá J, Oliveira JT, Ribeiro A (1994) The Beja-Acebuches Ophiolite (Southern Iberia Variscan Foldbelt): geological characterisation and geodynamic significance. Bol Geol Min 105:3-49

Rambaud F (1969) El sinclinal carbonífero de Rio Tinto (Huelva) y sus mineralizaciones asociadas. Mem IGME 71, $299 \mathrm{p}$

Ramírez Copeiro J, Navarro D (1982). Hoja Geológica Valverde del Camino ( ${ }^{\circ}$. 960) y Memoria. MAGNA (Mapa Geológico de España, 1:50.000), IGME, Madrid

Ramírez Copeiro J, Rosales F, Maroto S, Bellamy J (1988) Metodología de la Investigación que ha dado lugar al descubrimiento de una nueva masa de sulfuros al SO de Valverde del Camino (Faja Pirítica de Huelva). Proc. VIII Congr. Internac. Minería y Metalurgia, Oviedo, Spain: $24 \mathrm{pp}$

Ramírez Copeiro J, Maroto S, Rosales F, Faura J (1993) Metodología de Investigación de Yacimientos Ocultos bajo el Culm. Experiencia de Masa Valverde. Proc I Symp Sulfuros Polimetálicos de la Faja Pirítica Ibérica, Évora, Portugal, $19 \mathrm{p}$

Relvas JMRS, Barriga FJAS, Pinto A, Ferreira A, Noiva PC, Pacheco $\mathrm{N}$, Noiva $\mathrm{P}$, Barriga $\mathrm{G}$, Baptista $\mathrm{R}$, Carvalho $\mathrm{D}$, Olibeira $\mathrm{V}$, Munhá J, Hutchinson RW (2002) The Neves-Corvo deposit, Iberian pyrite belt, Portugal: impacts and future, 25 years after the discovery. SEG Spec Publ 9:155-176

Relvas JMRS, Barriga FJAS, Ferreira A, Noiva PC, Pacheco N, Barriga $G$ (2006) Hydrothermal alteration and mineralization in the NevesCorvo volcanic hosted massive sulfide deposit, Portugal. I. Geology, mineralogy, and geochemistry. Econ Geol 101:753-790

Ribeiro A, Pereira E, Dias R (1990a) Structure in the Northwest of the Iberian Peninsula. In: Dallmeyer RD, Martínez García E (eds) Pre-mesozoic geology of Iberia. Springer, Berlin, pp 220-236

Ribeiro A, Quesada C, Dallmeyer RD (1990b) Geodynamic evolution of the Iberian Massif. In: Dallmeyer RD, Martínez García E (eds) Pre-mesozoic geology of Iberia. Springer, Berlin, pp 399-410

Ruiz C, Arribas A, Arribas A Jr (2002) Mineralogy and geochemistry of the Masa Valverde blind massive sulphide deposit, Iberian Pyrite Belt (Spain). Ore Geol Rev 19:1-22
Sáez R, Pascual E, Toscano M, Almodóvar GR (1999) The Iberian type of volcano-sedimentary massive sulphide deposits. Miner Deposita 34:349-570

Sánchez Martínez S, Jeffries T, Arenas R, Fernández-Suárez J, GarcíaSánchez R (2006) A pre-Rodinian ophiolite involved in the Variscan suture of Galicia (Cabo Ortegal complex, NW Spain). J Geol Soc Lond 163:737-740

Schermerhorn LJG (1970) The deposition of volcanics and pyritite in the Iberian Pyrite Belt. Miner Deposita 5:273-279

Schermerhorn LJC (1971) An outline stratigraphy of the Iberian Pyrite Belt. Bol Geol Min 82:239-268

Silva JB (1989) Estrutura de uma geotransversal da Faixa Piritosa: Zona do Vale do Guadiana. Dissertation, University of Lisbon, $450 \mathrm{pp}$

Silva JB, Oliveira JT, Ribeiro A (1990) Structural outline of the South Portuguese Zone. In: Dallmeyer RD, Martínez García E (eds) Pre-mesozoic geology of Iberia. Springer, Berlin, pp 348-362

Simancas JF, Carbonell R, González Lodeiro F, Pérez Estaún A, Juhlin C, Ayarza P, Kashubin A, Azor A, Martínez Poyatos D, Almodóvar GR, Pascual E, Sáez R, Expósito I (2003) The crustal structure of the transpressional Variscan Orogen of SW Iberia: the IBERSEIS deep seismic reflection profile. Tectonics 22:1063-1078

Simmons BD (1973) Geology of the Millenbach massive sulphide deposit, Noranda, Quebec. Can Min Metall Bull 166(739):67-78

Spry PG, Marshall B, Vokes F (2000) Metamorphosed and metamorphogenic ore deposits. Rev Econ Geol 11, 310 pp

Strauss GK (1970) Sobre la geología de la provincial piritífera del suroeste de la Península Ibérica y de sus yacimientos, en especial sobre la mina de pirita de Lousal (Portugal). Mem. IGME 77, Madrid, $266 \mathrm{pp}$

Tornos F (2006) Environment of formation and styles of volcanogenic massive sulfides: the Iberian Pyrite Belt. Ore Geol Rev 28:259-307

Tornos F, González-Clavijo E, Spiro B (1998) The Filón Norte orebody (Tharsis, Iberian Pyrite Belt): a proximal lowtemperature shale-hosted massive sulphide in a thin-skinned tectonic belt. Miner Deposita 33:150-169

Tornos F, Solomon M, Conde C, Spiro BF (2008) Formation of the tharsis massive sulfide deposit, Iberian Pyrite belt: geological, lithogeochemical, and stable isotope evidence for deposition in a brine pool. Econ Geol 103:185-214

Vokes FM, Craig JR (1993) Post-recrystallisation mobilisation phenomena in metamorphosed stratabound sulphide ores. Mineral Mag 57:19-28

Williams D (1962) Further reflections on the origin of the porphyries and ores of Rio Tinto, Spain. Trans Inst Mining Metall 71:265-266

Williams PJ (1983a) The Genesis and metamorphism of the ArinteiroBama Cu deposits, Santiago de Compostela, Northwestern Spain. Econ Geol 78:1689-1700

Williams PJ (1983b) The mineralogy and metamorphism of some gahnite-bearing silicate inclusions in massive sulphides from Fornas, northwest Spain. Mineral Mag 47:233-235 